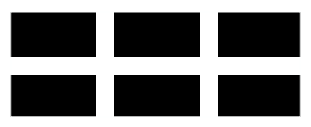

ThE William DAVIDSON INSTITUTE

AT THE UNIVERSITY OF MICHIGAN BUSINESS SCHOOL

\title{
Formation of social capital in Central and Eastern Europe: Understanding the gap vis-à-vis developed countries
}

\author{
By: Jan Fidrmuc and Klarita Gërxhani
}

William Davidson Institute Working Paper Number 766

April 2005 


\section{Formation of social capital in Central and Eastern Europe: Understanding the gap vis-à-vis developed countries ${ }^{\nabla}$}

\section{Jan Fidrmuc ${ }^{*}$ and Klarita Gërxhani* ${ }^{* *}$}

April 2005

Recent Eurobarometer survey data are used to document and explain the stock of social capital in 27 European countries. Social capital in Central and Eastern Europe - measured by civic participation and access to social networks - lags behind that in Western European countries. Using regression analysis of determinants of individual stock of social capital, we find that this gap persists when we account for individual characteristics and endowments of respondents but disappears completely after we control for aggregate measures of economic development and quality of institutions. Informal institutions such as prevalence of corruption appear particularly important.

Keywords: social capital, institutions, capitalism, transition

JEL codes: Z13, P37, O57, O17

\footnotetext{
$\nabla$ This research was initiated while Jan Fidrmuc was visiting AIAS whose hospitality he gratefully acknowledges. We are indebted to Robert Manchin of The Gallup Organisation Europe for giving us access to the Candidate Countries' Eurobarometer survey data. We are grateful to Victor Ginsburgh, Arthur Schram and Jelle Visser, as well as seminar participants at AIAS, ECARES, ZEI, and the 2004 European Public Choice Conference in Berlin for many helpful comments and suggestions.

* Brunel Business School, Brunel University; CEPR, London; and WDI, University of Michigan. Contact information: Brunel Business School, Economics and Finance Section, Brunel University, Uxbridge, UB8 3PH, United Kingdom. Email: Jan.Fidrmuc@brunel.ac.uk. Phone: +44-1895-266-528, Fax: +44-1895-203-384.

${ }^{* *}$ University of Amsterdam, Amsterdam Institute for Advanced Labour Studies (AIAS), Amsterdam School for Social science Research (ASSR), and Faculty of Economics and Econometrics (FEE), Plantage Muidergracht 4, 1018 TV Amsterdam, The Netherlands, email: k.gerxhani@uva.nl.
} 


\section{Introduction}

Over the last decade, the interest in studying social capital has grown enormously among sociologists, political scientists and economists alike. This increased interest resulted in a growing awareness and understanding of the role social capital plays in economic, social and political development of societies. Much credit for popularizing research on social capital is owed to the work of Robert Putnam (1993) who found evidence of a strong relationship between civic participation (measured as membership in voluntary organizations) and the quality of government across Italian regions. Knack and Keefer (1997) found that, in cross-country perspective, higher density of trust is associated with higher growth. Knack and Keefer's empirical analysis cements Coleman's (1988) assertion that social capital, just like other forms of capital, is productive and facilitates the attainment of goals that otherwise would not be possible. Accordingly, high stock of social capital increases individuals' ability and willingness to cooperate, improves monitoring and enforcement of contracts, and results in less information asymmetry. Social capital therefore lowers transaction costs, fosters innovation and dissemination of technology and thus leads to better economic outcomes. Offering an historical perspective on the issue, Greif (1994) argues that cultural underpinnings of social interactions in medieval societies played a crucial role in reducing free riding and opportunistic behavior.

Despite the increasing recognition of the importance of social capital for economic outcomes, our understanding of factors that determine the stock of social capital - at individual or aggregate levels - is still very limited. The previous literature centers on measuring social capital (usually at the aggregate, national level) and investigating its impact on the variable of interest, typically economic and/or institutional development of countries. Little attention is given to analyzing the factors that determine the individual stock of social capital and/or explaining the sources of differences across countries. ${ }^{1}$

This paper constitutes one of the few attempts to bridge this gap. Its contribution is three fold. First, we present a new and previously unavailable comparative dataset featuring a number of alternative measures of social capital for a sample of 27 European countries: including the member countries of the European Union and countries that (at the time the data were collected)

\footnotetext{
${ }^{1}$ Empirical studies of the determinants of social capital are fairly recent and tend to focus primarily on social capital in the United States. For a recent extensive overview of social capital literature, see Durlauf and Fafchamps (2004).
} 
were all candidates for the EU membership. Second, we analyze the determinants of the individual stock of social capital ${ }^{2}$, considering individual and aggregate (country specific) factors alike. Finally, we reconfirm the gap in the stock of social capital between developed Western countries and the formerly communist countries of Central and Eastern Europe. The existence of such a gap was highlighted by Paldam and Svendsen (2000) and Adam et al. (2004) who attribute it to the legacy of communism. Paldam and Svendsen, for example, posit that the communist regime destroyed most or all of the existing social capital in these countries, which helps account for the slow pace of transition after the regime collapsed. We present a more optimistic assessment. Our findings suggest that the gap in social capital between Western and Eastern European countries can be attributed to the lower level of economic development and the lower quality of institutions in the latter countries. As such, it should gradually disappear as the post-communist countries catch up with respect to their economic development and the quality of institutions. We also discuss, albeit very tentatively, the potential impact that EU enlargement can have on intra-European convergence in social capital levels.

In a similar study, Glaeser, Laibson and Sacerdote (2002) develop a theoretical model of individual-level investment in social capital and test it in the context of a single country: the United States. Our study confirms many of their key findings. However, because their analysis is limited only to a single country, it fails to shed light on cross-country differences in (individual and aggregate) stock of social capital. In contrast, an important innovation of our paper lies exactly in its use of large international samples of individual respondents, thus permitting the simultaneous identification of individual-level and societal-level determinants of social capital in Europe.

Since the source of our data are multiple Eurobarometer surveys (commissioned by the European Commission), our analysis is necessarily constrained to the member countries of the EU and candidates for membership in the EU. Though there has been some research studying social capital in developed and transition countries separately, ${ }^{3}$ to the best of our knowledge, we are the first to systematically develop and jointly analyze measures applicable to both groups of

\footnotetext{
${ }^{2}$ We employ the same definition as in micro-economic literature, according to which individual social capital consists of one's social attributes that can be used to benefit while interacting with other individuals. For a detailed discussion, see Glaeser et al. (2002).

${ }^{3}$ With the exception of Cyprus, Malta and Turkey, all candidate countries are former communist countries. This shared legacy of communism and central planning is one of their main distinguishing features in comparison to the old member countries of the EU. Therefore, the on-going post-communist transition process is an important aspect of our analysis.
} 
countries, and moreover relate the analysis specifically to the enlargement process. So far, when studying the enlargement process or, more generally, the process of transition from communism to democracy and market economy, the focus has been on real and nominal convergence and convergence in formal institutions (i.e., laws and regulations). Informal institutions (i.e., norms, relationships, and rules of behavior) have not received much, if at all, attention.

In this paper, we draw guidance from recent developments in the new institutional economics. That literature stresses the importance of informal institutions and their role in explaining differences across developed and less developed (both developing and transition) countries (see North, 1990; Feige, 1997). Given that the formerly communist countries are still going through transformation, involving tremendous institutional restructuring, it is very important that informal institutions develop parallel to formal institutions, so that the two remain compatible. If this happens, the transaction costs of such institutional restructuring, expressed in the form of predatory activities such as corruption and tax evasion, will decrease (see Pejovich, 2003). On the other hand, if formal and informal institutions are in conflict, more of such predatory activities may be expected, as shown empirically by Gërxhani (2004).

The paper is organized as follows. The next section reviews the previous literature about social capital and its measurement. Section 3 introduces our data and explains the measures that we use. Section 4 provides empirical insights on the individual determinants of social capital. Section 5 completes the analysis by integrating individual- with aggregate-factors. Section 6 concludes.

\section{Social capital and its measurement}

\subsection{A brief review of the literature}

As a consequence of the variety of aspects it covers, social capital is defined in various ways. Although the concept itself originates from Loury (1977) and later Bourdieu (1986), Coleman's (1988) definition has become the most popular. Coleman, presenting a sociologist's view, defines social capital as a component of human capital that allows members of a given society to trust one another and cooperate in the formation of new groups and associations. Putnam (1993: 664-665), a political scientist, offers a broader definition of social capital as encompassing "features of social life - networks, norms, and trust - that enable participants to act together more effectively to pursue shared interests”. Stiglitz (2000), an economist, sees social capital - 
consisting of tacit knowledge, networks and reputation - as a social means to tackle moral hazard and incentive issues. Broadly speaking, all these definitions refer to trust, cooperative behavior, and networks between groups, as essential components of social capital (Knack and Keefer, 1997). In the presence of trust, cooperation will be easier and therefore the frequency and density of networks is expected to be higher. ${ }^{4}$ Interaction through networks in turn enhances trust and cooperative ability. According to Dasgupta (1988), social capital can make economic transactions more efficient by giving parties access to more information, enabling them to coordinate activities for mutual benefit, and reducing opportunistic behavior through repeated transactions. In addition, Putnam (1993) argues that participation in civil associations can contribute to the effectiveness and stability of democratic governments, both because of their 'internal' effects on individual members and because of their 'external' effects on the wider polity. "Internally, associations instill in their members habits of cooperation, solidarity, and public-spiritedness. Externally, ‘interest articulation’ and 'interest aggregation’ are enhanced by a dense network of secondary associations” (Putnam, 1993: 89-90). ${ }^{5}$

The economic and institutional development of a country may have an important influence on social capital. Agreeing with social psychologists, Greif (1994) argues that the level of development and the organization of an economy may determine whether societies develop 'collectivist' or 'individualist' characteristics. The former tend to build up group-specific social capital (i.e., pertaining to one's family, religious or ethnic group) and rely on informal enforcement, whereas the latter are based on interaction across groups who invest in generalized social capital and formal enforcement rules.

At first instant, an analogy can be observed between Greif's categorization of societies and the two groups of countries analyzed in this paper. Basically, it can be argued that because the EU member states (i.e., developed countries) are generally characterized by a high density of economic transactions among different groups; well-established institutions; high level of generalized trust and participation in civil associations; and a bottom-up structure of economic transactions, they fall into the category of individualist societies. Candidate countries (i.e., less developed countries), on the other hand, with more underground economy; corruption and state

\footnotetext{
${ }^{4}$ The direction of causality is not clearly resolved, however. Gambetta (1990), for example, argues that trust follows rather than causes cooperation.

${ }^{5}$ Nevertheless, it is now widely recognized that social capital may also have less desirable consequences. For an extensive discussion, see Portes (1998).
} 
failure; low level of generalized trust and participation in civil associations; and a top-down structure of economic transactions, come closest to Greif's description of collectivist societies. However, with the exception of Cyprus, Malta and Turkey, the rest of candidate countries are post-communist countries. Recent research on social capital in these countries has put forward a so-called dictatorship theory of missing social capital (see Raiser, 1999; Kunioka and Woller, 1999; and Paldam and Svedsen, 2000, 2001). According to this theory, dictatorships destroy social capital, group-specific and generalized alike. Moreover, they create such conditions that when dictatorships collapse, societies may even accumulate 'negative' social capital, which in turn impedes economic growth. During the communist dictatorship in most of the candidate countries, 'positive' social capital decreased and 'negative' social capital built up. This 'negative' social capital took the form of underground activities, corruption or organized crime. The gap, created by the sudden destruction of old institutions and the creation of new ones, provided a favorable environment for the persistence or even further accumulation of 'negative' social capital throughout transition. ${ }^{6}$

The dictatorship theory of missing social capital adds a new dimension to Greif's categorization. Within the so-called collectivist societies, there are countries which due to the legacy of communism may possess neither generalized social capital nor group-specific social capital, and may even have an inherited stock of 'negative' social capital.

Given the main argument in the literature that the generalized social capital is more beneficial to a society as a whole in the long run, the focus of this paper is on this type of social capital.

\subsection{Measures of social capital ${ }^{7}$}

The previous literature attaches the label social capital quite liberally to a number of concepts that are not necessarily equivalent to each other. The following are the most popular empirical measures of generalized social capital:

\footnotetext{
6 The extent to which this 'negative' social capital (i.e., underground activities or corruption) has emerged varies per country. Rose (2000) relates it to the supremacy of the totalitarian regime these countries experienced during communism. The same line of argument can be found in Putnam et al. (1993), where the low level of social capital in South Italy is attributed to the long absolutist regime of the Kingdom of Sicily.

${ }^{7}$ For a critical review of empirical analysis of social capital, see Durlauf (2002).
} 
1 Civic participation, generally captured by membership in voluntary organizations, pioneered by Putnam’s (1993) seminal work on Italian regions. Through membership in voluntary organizations, one learns to interact with other people - both acquaintances and strangers - in a cooperative manner and to solicit their cooperation to achieve a shared objective. ${ }^{8}$ As such, voluntary organizations introduce their members to advantages and practice of collective action (Olson, 1982). Later work further distinguishes between Putnamesque and Olsonian organizations (see Knack and Keefer, 1997). The former, such as educational, sport and art clubs, religious and charitable organizations, and youth groups, allow their members to build up social capital and pursue common goals without imposing negative externalities on the rest of the society. The latter, including political parties and movements, trade unions, professional associations, and various interest groups, tend to engage in collective action that may reconfigure redistribution systems in their favor at the expense of the rest of the society. Therefore, in contrast to Putnamesque groups, which are thought to play a positive role in the society, the impact of Olsonian groups may be distinctly negative.

2 Trust, popularized by Fukuyama (1995), is the most commonly used empirical measure of social capital. Its empirical popularity is largely due to the availability of extensive crosscountry survey data on generalized trust (collected within the framework of the the World Value Surveys program). Typically, trust is defined as the extent to which people find strangers trustworthy.

3 Density of networks as a measure of the density of ties between individuals. Depending on whether the ties are within one group or across different groups, networks can be classified as informal and formal (or specific and general), respectively. The latter include also alumni associations and clubs such as the Rotary Club, in which case it can be argued that formal networks may partially overlap with membership in voluntary organizations. Informal networks, on the other hand, embody informal relations among friends, members of (extended) family, colleagues, and the like.

\footnotetext{
${ }^{8}$ For instance, participating in team sports or playing an instrument in an orchestra requires an extraordinary degree of cooperation, coordination and discipline. The fans of The Simpsons television series may recall Lisa Simpson's unsuccessful attempt at individualism when playing the saxophone in a school orchestra, which illustrates this point rather well.
} 
The following section provides a description of the data and methodology used, and the way social capital is operationalized in this paper.

\section{Social capital in Europe}

Our measures of social capital utilize several recent Eurobarometer surveys commissioned by the European Commission and carried out by Gallup Europe. ${ }^{9}$ Two types of surveys are used. First, standard Eurobarometer surveys (henceforth EB) were carried out in the 15 countries that were members of the European Union at the time. ${ }^{10}$ Second, as of 2000, similar surveys were carried out also in the candidate countries. ${ }^{11}$ These surveys are referred to as Candidate Countries Eurobarometer surveys (henceforth CCEB). The two survey modules are implemented using essentially the same methodology and frequently contain similar questions. ${ }^{12}$ Importantly, three recent EB surveys (in 1998, 1999 and 2001) featured questions that address various aspect of social capital, and identical questions were included in the Spring 2002 CCEB survey. We can therefore carry out comparative analysis including both sets of countries.

The EB/CCEB surveys featured questions that can be used to gauge three aspects of social capital: civic participation, access to social networks, and altruism (philanthropic generosity). Table 1 presents the aggregate figures.

\footnotetext{
${ }^{9}$ We are grateful to Robert Manchin of The Gallup Organisation Europe for kindly making these data available to us.

${ }^{10}$ Austria, Belgium, Denmark, Finland, France, Germany, Greece, Italy, Ireland, Luxembourg, Netherlands, Portugal, Spain, Sweden, and the United Kingdom.

${ }^{11}$ Bulgaria, Cyprus, Czech Republic, Estonia, Hungary, Latvia, Lithuania, Malta, Poland, Romania, Slovakia, Slovenia, and Turkey. We refer to these countries as candidates for membership because that was their status at the time the surveys were carried out. Ten of these countries have become members of the EU as of May 2004.

${ }^{12}$ See WZB (2003). The surveys are carried out by means of face-to-face interviews, with approximately 1,000 respondents per country, except the following countries: Germany (1,000 respondents in each West and East Germany), United Kingdom (additional 300 respondents in Northern Ireland), Poland and Turkey (2,000 respondents each), and Cyprus, Luxembourg and Malta (500 respondents each). The overall sample size thus is approximately 16,000 for the EB surveys and 14,000 for the CCEB. The same questionnaire is used in all countries of the respective group (EB or CCEB), the questionnaire is translated and interviewers are local staff. The surveys are constructed so as to be broadly representative at the national level. The data report East Germany and Northern Ireland as separate entities, and we retain this distinction.
} 


\section{TABLE 1 HERE}

The first measure in Table 1 is the average civic participation, or membership in voluntary organizations. Specifically, the respondents were asked: "From the following list, could you tell me in which of these organizations do you actively participate?”. The list of organizations included charities (social, communal or religious); religious or parish organizations other than charities; cultural or artistic organizations; trade unions or political parties; human rights movements or organizations; organizations for the protections of nature, animals and the environment; youth organizations such as scouts or youth clubs; consumer organizations; sports clubs and associations; hobby clubs; and other clubs or organizations. It should be stressed that the question asks the respondents to list those organizations in which they actively participate. We believe that active participation is crucial for the link between membership in voluntary organizations and social capital: one builds up social capital through interacting with fellow members and participating in common activities, not by paying membership dues and holding a membership card. Unfortunately, the question only records each type of organization, thereby disregarding multiple memberships in similar organizations (for example, one may be a member of two or three different sports clubs). As the survey asked about membership in 11 types of organizations (including an 'other' category), the maximum value that this variable can attain is 11.

In the adjacent columns, we have split the membership count into Putnamesque and Olsonian variables. The former are charities; religious or parish organizations other than charities; cultural or artistic organizations; youth organizations; sports clubs and associations; hobby clubs; and other clubs or organizations. The latter include trade unions or political parties; human rights movements or organizations; organizations for the protections of nature, animals and the environment; and consumer organizations.

No question on trust was included in the Eurobarometer surveys. For comparative purposes, the last two columns of the first part of Table 1 report country averages of level of generalized trust as measured by the two most recent rounds of the World Value Surveys: WVS1990 and WVS1996. Specifically, the figures measure the fraction of respondents who in response to the following question: “Generally speaking, would you say that most people can be trusted or that 
you can't be too careful in dealing with people?" declared that most people could be trusted. This is, however, not a measure we use to analyze social capital. ${ }^{13}$

The first three columns of the second part of Table 1 present measures of access to social networks that one can rely on in need. Specifically, respondents were asked: "If you had any of the following problems (you were feeling depressed; you needed help finding a job for yourself or a member of your family; or you needed to borrow money to pay an urgent bill, like electricity, gas, rent or mortgage) is there anyone you could rely on to help you, from outside your own household?”. As these three networks are rather different in nature, we codify each as a separate binary variable equal to 1 if the individual has access to the network in question and 0 otherwise.

The last two columns of the second part of the table report the average extent of altruism among the respondents, based on the following two questions: "Now thinking about poor or socially excluded people, in the last twelve months, have you done the following (given money or goods to poor or socially excluded people; given up some of your time to help poor or socially excluded people) at least once a month, less often or have you not done it?". The answers are coded as 0 for those who have never contributed money or given up their time, 1 for those who have done so less than once a month, and 2 for those who have done so more often.

The figures for each measure of social capital are presented in descending order. The average figures for the EU members (before the latest enlargement) and the candidate countries are also included. There are clear similarities in the ordering of countries. Whether the various indicators measure the same underlying phenomenon (i.e., social capital) or not can be assessed by means of simple correlation analysis. Table 2 presents the correlation matrix for the various measures at the aggregate level. Clearly, civic participation is very closely correlated with aggregate generalized trust: the correlation coefficients between trust and average participation, Putnamesque and Olsonian groups are all close to 0.8. The correlation analysis further suggests that Putnamesque and Olsonian groups are not necessarily that different: countries with high

${ }^{13}$ Some argue that generalized trust is not an adequate measure of social capital, because it does not differentiate between trust and trustworthiness (see Bornhorst et al., 2004), and because it is context-dependent. For example, in an ethnically polarized society, a member of the minority group - even if perfectly trustworthy- will often neither be trusted by the majority of population nor him(her)self trust the members of the majority. In addition, the same individual would report considerably different generalized trust depending on the wording (or understanding) of the question: he or she would report high trust vis-à-vis members of own group but low trust vis-àvis members of the majority group. For a noteworthy study, using experimental and field methods to measure both concepts of trust and trustworthiness, see Glaeser et al. (2002). 
participation in one group also display high levels of participation in the other. Similarly, both groups are closely correlated with generalized trust. Nonetheless, for the sake of completeness, we retain the distinction between Putnamesque and Olsonian groups in the remainder of our analysis.

\section{TABLE 2 HERE}

Countries where social networks are more prevalent tend to display also high levels of civic participation. A similarly high degree of correlation holds between networks and generalized trust. The only indicator that stands out as largely orthogonal to either civic participation or generalized trust is altruism. In contrast to Putnam's (2001) finding, our data find both measures as being at best weakly correlated with the remaining variables.

Finally, based on Table 1, two observations can be made about the distribution of social capital across countries. First, of all the indicators listed in Table 1 except giving up one's time to help the poor and socially excluded, all show the EU member countries as having on average higher stock of social capital than the candidate countries. Given that the vast majority of the candidate countries are post-communist countries, this observation seems to confirm the assertion of Paldam and Svendsen (2000, 2001) and Adam et al. (2004) that communism destroyed social capital by discouraging social interactions outside one's immediate network of friends and family. Second, there is a considerable degree of variation within both groups of countries - some candidate countries have very favorable endowments of social capital whereas some EU member countries fare rather poorly. A detailed analysis is provided in the following sections.

\section{Individual determinants of social capital}

In section 2, we described three types of indicators - civic participation, social networks, and altruism - that, as argued in the literature, are predicted to be closely correlated with the stock of social capital. Based on our data, we showed that at the aggregate level, civic participation and social networks are indeed closely correlated with each other as well as with generalized trust, whereas correlation is at best weak vis-à-vis altruism. The high correlation of our measures of civic participation and networks with generalized trust - the variable used most frequently to 
study social capital - makes us confident about using these two measures to analyze factors that determine individual stock of social capital.

We view social capital as a productive asset that is built up through investment: it takes time, effort and often a financial outlay to accumulate social capital. Once built up, as with other types of capital (physical and human), social capital generates a return, depreciates over time, and needs to be kept up to prevent it from depreciating and becoming obsolete. An individual's investment in social capital therefore is expected to depend on the individual's socio-economic characteristics, in particular age, family background, level of human capital (education and occupation), and income (see Coleman, 1988). While our approach in this paper is purely empirical, this notion of social capital can be supported by standard economic theory, as is done by Glaeser et al. (2002), whereby the individual's stock of social capital is the outcome of an individual maximization problem with limited resources. In addition, in line with our discussion in section 2, we also consider aggregate determinants of social capital such as economic development and quality of institutions. The latter (e.g., the rule of law or corruption) are likely to affect the return on investment in any type of capital, including the social one. Individuals in countries with poor institutions, therefore, may be discouraged from investing and, in turn, will acquire less generalized social capital than their counterparts in countries with better institutional environment. According to Paldam (2002), more corruption leads to lower generalized trust. He argues that corruption is by far the best available measure of 'negative' social capital.

The dependent variables are the two measures introduced in section 3: civic participation, and social networks. ${ }^{14}$ As very few individuals participate in more than 3 organizations, we recoded civic participation so that it takes values $0,1,2$, or 3 , with the last being ascribed to anyone who participates in three or more organizations. The participation in Putnameque and Olsonian groups was recoded in the same way. Social networks remain defined as above: zeroone dummy variables indicating access to the respective network.

As a first step, we relate the individual stock of social capital to various individual-level socio-demographic characteristics: gender, age, marital status, education, occupation, residency in urban vs. rural areas, and income. To account for country-specific factors, we also include

${ }^{14}$ Despite the low correlation of altruism with either civic participation or social networks, using the two measures of helping the poor and socially excluded yields results broadly similar to those obtained with civic participation and social networks. Because of both space considerations and the slightly lower confidence that we have in this measure being indicative of the stock of social capital, the results obtained with altruism are not reported here. They can be obtained from the authors upon request. 
country dummies (East Germany and Northern Ireland are reported as separate entities in the EB data sets; because of the potentially special nature of these two regions, we retain this distinction). Table 3 reports the regression results obtained with civic participation for the candidate countries $^{15}$, while Table 4 presents those for the EU member states. Because of the potentially important difference between Putnamesque and Olsonian groups, we carry out the regression analysis first with overall participation and then separate it into the two types of voluntary organizations.

\section{TABLES 3 AND 4 HERE}

Looking first at the overall civic participation, a number of individual characteristics appear to shape individual investment in social capital, and these determinants tend to be similar in the candidate and member countries of the EU. Education is particularly important: respondents with secondary or university education or those who are still studying are more likely to actively participate in voluntary organizations than those with primary education (the omitted category). Overall civic participation increases also with income: more well-to-do individuals tend to acquire more in social capital than those who are less affluent. Civic participation seems to follow a hump-shaped path over an individual's lifetime - this pattern is not significant for the candidate countries, however. ${ }^{16}$ The unemployed, retirees, house-persons, and females tend to display significantly lower levels of overall civic participation.

When comparing participation in Putnamesque and Olsonian groups, only a few differences emerge. Education and income are positively correlated with active participation in both types of groups. The age profile of social capital over one's lifetime is more pronounced and steeper for Olsonian groups - participation in collective action aimed at distributive objectives increases and subsequently falls more dramatically with age than participation in Putnamesque groups. The unemployed, retirees, house-persons and females, on the other hand, tend to stay away more from Olsonian groups than from Putnamesque ones - they pursue their interests and hobbies but

15 Turkey is not included in our analysis because it differs from the other candidate countries in many important aspects such as the level of development, cultural and religious traditions, and because of its unclear status with respect to membership in the EU. Nonetheless, including Turkey in the regressions or omitting also Cyprus and Malta (which do not share the post-communist legacy characteristic of the other candidate countries) produce qualitatively very similar results and are therefore not reported here but can be obtained upon request.

${ }^{16}$ It peaks around the of age of 50 for the EU members and 70 for the candidates, and subsequently declines. 
not distributional objectives. Married people are less likely to participate in Putnamesque groups but more likely to get organized in Olsonian ones. The self-employed and white-collar workers, finally, tend to participate more often in Putnamesque rather than in Olsonian groups. ${ }^{17}$

Using access to social networks (i.e., networks outside the immediate household) instead of civic participation leads to very similar results, as Tables 5 and 6 reveal. The most notable difference is the effect of age. In both member states and candidate countries, older individuals tend to have more limited access to social networks. The relationship may be U-shaped, whereby the decline in access slows down at a higher age. ${ }^{18}$ Women have an easier time to find consolation when depressed and financial relief when in need of money - but are less likely than men to find a job using their social contacts. The remaining variables affect access to social networks in a manner very similar to their effect on civic participation: education, income, being a student, self-employed, or a white-collar worker are all positively correlated with the availability of social networks. Being unemployed, on the other hand, translates into more limited access to social networks.

\section{TABLES 5 AND 6 HERE}

In summary, most of our findings show not only consistency across our two measures of social capital, but also similarity in the candidate and EU member countries. The positive relationship between education and the stock of social capital may indicate that social and human capital are complementary - individuals who acquire a high stock of one also invest in the other. ${ }^{19}$ In addition, education may reduce the cost of investing in social capital by improving

\footnotetext{
${ }^{17}$ We thought initially that this result for the self-employed may be due to the fact that the survey questionnaire did not feature professional associations and guilds (which are essentially Olsonian in nature) as a separate category; therefore, members of such associations would report participation in the 'other' category, which we included among Putnamesque groups. When looking at logit results for individual membership categories, we find that only in the EU member countries the self-employed are significantly more likely to report participation in 'other' organizations. The above-reported result indicating higher probability of the self-employed being members of Putnamesque groups, may be therefore driven by their more frequent participation in cultural, sports, hobby and human-rights organizations (further results on civic participation for individual categories of groups can be obtained from the authors upon request).

${ }^{18}$ The minimum point is reached at the age of $60-65$ for the candidate countries and 98 for the current members.

${ }^{19}$ For an early evidence and discussion, see Coleman (1988).
} 
one's communication skills, or by generating positive externalities. ${ }^{20}$ Regarding the positive effect of income, Glaeser et al. (2002) report a similar finding in their analysis based on US data, and find it puzzling as it contradicts their theoretical prediction that investment in social capital should fall with opportunity cost of time (wage). This finding could be reconciled by recognizing that obtaining social capital may require not only time but also monetary outlays. Furthermore, this result can be indicative of reverse causality. As income is contemporaneous to social capital (unlike education which is typically acquired at a relatively young age), finding positive correlation between income and social capital may simply document the positive impact of social capital on earnings. ${ }^{21}$ The negative effect of being unemployed, retirees, house-persons and female on the stock of social capital reflects their exclusion from the labor market. These groups of individuals, especially females, are expected to have a higher stock of group-specific social capital than the generalized one (see Stoloff et al., 1999; and WB, 2002).

Since the individual determinants of social capital are to a large extent very similar in the candidate and EU member countries, we hypothesize that country-specific factors play an important role in accounting for the apparent gap (cf. section 3), as insinuated by the high and significant country dummies in tables 3-6. In the next section, therefore, we consider aggregate determinants of social capital.

\section{Economic development and institutional quality}

In this section, we extend the analysis of determinants of individual stock of social capital by considering, alongside individual characteristics, aggregate factors such as economic development and the quality of institutions. In doing so, we hope to gain additional insights into the factors that underlie the formation of social capital at the individual level. Moreover, countryspecific economic and institutional conditions may help account for the gap in the level of social capital between the candidate countries and the member states of the EU.

As we want to explain the differences in formation of social capital across countries, we merge the data for both candidate and member countries of the EU and include a dummy variable for the candidates (while dropping the country dummies). Obtaining a significant

\footnotetext{
${ }^{20}$ This finding supports the view of those researchers who believe in a positive relationship between education and generalized social capital. For a discussion, see Helliwell and Putnam (1999).

${ }^{21}$ See Uslaner (1996), Knack and Keefer (1997), and Narayan and Pritchett (1999) for more evidence and detailed discussions.
} 
coefficient on the 'candidate' dummy would indicate that there is indeed a gap between the candidates and members that cannot be explained by the variables included in the regression.

At first, we run the regressions only with individual characteristics. These results are reported in Table 7, again for civic participation (overall active participation in voluntary organization as well as participation in Putnamesque and Olsonian groups), and for access to social networks. The impact of individual characteristics mirrors our previous findings: age, education, income, occupation and employment status are all important determinants of the individual stock of social capital (note, however, that in this merged data set the self-employed now display significantly lower civic participation whereas before the self-employed dummy appeared either with positive or insignificant coefficient).

The results of the first regression, with overall civic participation, confirm the observation (based on country averages reported in Table 1) that the candidate countries lag significantly behind the EU member countries in their stock of social capital: the coefficient on the candidate dummy is negative and strongly significant. When distinguishing between Putnamesque and Olsonian groups, an interesting result appears: candidate countries do better than member countries with respect to participation in Putnamesque groups, but do worse in the case of Olsonian groups. The coefficient estimate, however, is much lower (in absolute value) for the former than for the latter. Hence, when the two types of groups are pooled together in 'overall civic participation', the lower participation in Olsonian groups more than offsets the effect of higher participation in Putnamesque ones, and the candidate countries thus appear to lag behind the member countries. This result is particularly interesting because it cannot be readily discerned from country averages in Table 1; in that table, candidate countries appear to lag behind with respect to both, Olsonian and Putnamesque groups. It is only after accounting for individual characteristics that this striking difference becomes apparent.

A possible explanation for this finding is a general dissatisfaction with, and lack of trust in, formal political groups, parties, and unions in the candidate countries, and as a consequence a dislike for participation, and lower degree of unionization of the labor force. Both can be attributed to the legacy of communism (common to all candidate countries except Cyprus, Malta and Turkey) when political activity was not voluntary and trade unions were highly politicized and subordinated to the communist party. 
The gap in social capital also appears when considering access to social networks: across all three sub-measures, the candidate countries appear to lag significantly behind the EU member countries.

\section{TABLE 7 HERE}

To assess the impact of country-level economic and institutional environment, we augmented the regressions with a number of aggregate indicators of economic development and institution quality: GDP per capita (in purchasing-power-parity terms); the Gini coefficient of income inequality; the Transparency International corruption-perception index (inverted so that higher values indicate lower corruption); the average of indexes of political freedom and civil liberties reported by the Freedom House (in alternative regression specifications, we replaced this democracy index with a measure of the fraction of years since 1972 that the country was classified by the Freedom House as free or partially free); economic freedom index compiled by the Frasier Institute; and the average economic growth over preceding three years. Though we tried several alternative regression specifications ${ }^{22}$, the results are broadly similar and therefore we report, in Table 8, only one of the most general regression specifications, relating individual stock of social capital to economic development (proxied by per-capita GDP), income inequality, pervasiveness of corruption, and economic freedom. ${ }^{23}$

\section{TABLE 8 HERE}

The most interesting finding is that once aggregate economic development and institutional quality are controlled for, the candidate countries are no longer different from the EU members with respect to their stock of social capital. Moreover, the candidate countries appear with a positive coefficient in the first three regressions, indicating that the candidate countries display significantly higher active participation in voluntary organizations, Putnamesque and Olsonian alike, than one would expect given their level of economic development and institutional quality. In fact, already when controlling only for the GDP per capita, the significance of the candidate

\footnotetext{
${ }^{22}$ Additional results can be obtained from the authors upon request.

${ }^{23}$ Note that we adjusted the standard errors for the fact that aggregate and individual variables are measured at different levels of aggregation.
} 
dummy is driven below conventional levels, or the dummy appears significantly positive, in all six regressions (specifically, the dummy appears with a significantly positive coefficient in the regression with Putnamesque groups, and not significant otherwise).

The impact of country-specific economic and institutional conditions is in line with what one would generally expect. Higher per-capita income tends to be associated with more frequent civic participation, although the pattern often appears not significant when additional aggregate indicators are included in the regression (as is the case in the regressions reported in Table 8). Individuals in countries with high income inequality and especially widely-spread corruption (the strongest significant variable) tend to acquire less social capital. Economic freedom seems to encourage investment into social capital.

These patterns are very intuitive. Income inequality reflects the intensity of social conflict in the country (see Knack and Keefer, 1997 and Rodrik, 1999). Socially polarized countries, not surprisingly, end up with lower investment in generalized social capital. Rampant corruption and extensive regulation of the economy reduce the returns on any kind of investment, whether it is into social capital or other productive capacities. Therefore, both formal and informal institutions (economic freedom belonging to the former, while corruption being an expression of the latter) matter for individual acquisition of generalized social capital.

Finally, it is reassuring to note that the individual socio-demographic attributes (education, occupation, unemployment and income) remain strongly significant after controlling for aggregate determinants of social capital. Hence, both individual and aggregate factors play important roles in underlying individual decisions on acquiring social capital.

\section{Conclusion}

Using recent Eurobarometer surveys, this paper presents new and previously unavailable comparative data featuring a number of alternative measures of social capital for a sample of 27 European countries: including the member countries of the European Union and countries that at the time the data were collected were candidates for the EU membership (mainly Central and Eastern European countries). Focusing on civic participation and access to social networks as two key measures of social capital, we analyze the determinants of the individual stock of social capital, considering individual (i.e., socio-demographic characteristics) and aggregate (i.e., economic development and quality of institutions) factors alike. The results confirm important 
differences in the stock of social capital between these two groups of countries within Europe. The analysis reveals, however, that while the stock of social capital at the individual level is affected by very similar factors in both groups of countries, the differences in individual-level determinants cannot fully account for the gap at the aggregate level. Once we also include aggregate measures of economic development and quality of institutions, the gap disappears. This finding thus indicates that the low average stock of social capital in Central and Eastern European countries can be attributed to the lower level of economic development and the lower quality of institutions in candidate countries. With respect to the latter, the effect of corruption seems to be particularly important.

Although a convergence in formal institutions between the member states and the candidate countries has to a large extent been accomplished, there remains a mismatch between these 'harmonized' formal institutions and the existing informal institutions in the candidate countries (see Pejovich, 2003, for a broader discussion). This lack of correspondence, embodied in the form of corruption and other predatory activities, may be the underlying reason of the persisting significant divergence with respect to social capital. This argument can be reinforced by our finding that the participation of candidate countries in Olsonian groups (formal political groups and parties, or unions) is much lower than in Putnamesque groups, reflecting individuals' lack of trust in formalized institutions.

The expectation is that the enlargement of the European Union will contribute to more open democratic governments and policies in the candidate countries. This will, in turn, promote public policies that discourage rent-seeking, motivate a rewarding scheme of leaderships based on performance, generalized public trust on state's actions, and civic spirit. Thus, once Central and Eastern European countries catch up with the West in terms of economic development and institutions, they are very likely to close the gap in social capital as well. For this to be possible, however, a gradual harmonization of formal rules and informal norms between the two groups of countries should be of primary importance.

Finally, our analytical framework does not facilitate comprehensive resolution of causality issues related to social capital (see Durlauf, 2002). Importantly, causality cannot go from individual stock of social capital to aggregate economic development and institutions, as each individual is too small to have much impact on aggregate outcomes. Moreover, it is indisputable that the transition economies owe their unfavorable economic and institutional development 
primarily to history and geography - having found themselves in the Soviet zone of influence at the end of the World War II. A question that poses a greater challenge is whether individual socio-economic characteristics determine individual stock of social capital or are in fact determined by it. Education and, though to a lesser extent, occupation are typically acquired at a relatively young age whereas social capital stock changes over one's lifetime (as the impact of age on social capital discussed above suggests). Therefore causality is more likely to go from education and occupation to social capital rather than the other way around - although a simultaneous relationship cannot be excluded. However, social capital may have an important effect on one's earnings and employment status (including the probability of becoming unemployed). Ideally, to resolve the question of causality satisfactorily, we would require longitudinal panel data where we could observe the evolution of both social capital and individual characteristics over time. Nevertheless, our interpretation of the observed correlation between individual socio-economic characteristics and social capital is consistent with the predictions of the theoretical model formulated by Glaesser et al. (2002). Therefore, we feel confident enough in interpreting the findings as indicative of causality going from individual socio-economic characteristics to individual stock of social capital, with the proviso that the relationship can be in fact simultaneous in some cases. 


\section{References}

Adam, F., Makarovic, M., Roncevic, B., and Tomsic, M., 2004, The Challenges of Sustained Development: The Role of Socio-Cultural Factors in East Central Europe, Budapest and New York: Central European University Press.

Bornhorst, F., A. Ichino, K. Schlag and E. Winter, 2004. Trust and Trustworthiness among Europeans: South-North Comparison, CEPR Discussion Paper No. 4378, Centre for Economic Policy Research, London.

Bourdieu, P., 1986. The forms of capital. In J.G. Richardson, Handbook of theory and research for the sociology of education (pp. 241-58), New York: Greenwood.

Coleman, J.S., 1988. Social capital in the creation of human capital. The American Journal of Sociology 94: 95-120.

Dasgupta, P., 1988. Trust as a commodity. In Gambetta, D. (Ed.), Trust: Making and breaking cooperative relations, pp. 49-72, Oxford: Basil Blackwell.

Durlauf, S.N., 2002. On the Empirics of Social Capital. The Economic Journal, 112: 459-479.

Durlauf, S.N., and M. Fafchamps, 2004. "Social Capital”. NBER Working Paper 10485, National Bureau of Economic Research, Cambridge, Massachusetts.

Feige, E.L. 1997. "Underground Activity and Institutional Change: Productive, Protective and Predatory Behavior in Transition Economies", in Joan M. Nelson, Charles Tilley and Lee Walker (eds.) Transforming Post-communist Political Economies, pp. 21-35. Washington, D.C.: National Academy Press.

Fukuyama, F., 1995. Trust: The Social Virtues and the Creation of Prosperity. New York, NY: Free Press Paperbacks.

Gambetta, D., 1990. Can we trust trust? In Gambetta, Diego (Ed.), Trust: Making and breaking cooperative relations, pp. 213-237, Oxford: Basil Blackwell

Gërxhani, K., 2004. Tax evasion in transition: Outcome of an institutional clash? Testing Feige's conjecture in Albania. European Economic Review, 48 (4): 729-745.

Glaeser, E.L., D. Laibson,; J.A. Scheinkman, and C.L. Soutter, 2000. Measuring Trust. The Quarterly Journal of Economics, 115: 811-46.

Glaeser, E.L., D. Laibson, and B. Sacerdote 2002. An Economic Approach to Social Capital. The Economic Journal, 112: 437-458.

Greif, A., 1994. Cultural beliefs and the organization of society: A historical and theoretical reflection on collectivist and individualist societies. Journal of Political Economy, 102(5):: 912-50.

Helliwell, John F. and Putnam, Robert D., 1999. Education and social capital, NBER Working paper 7121, National Bureau of Economic Research, Cambridge.

Knack, S., and Keefer, P., 1997. Does Social Capital Have an Economic Payoff? A CrossCountry Investigation. Quarterly Journal of Economics, 112 (4): 1251-1288.

Kunioka, T., and Woller, G.M., 1999. In (a) democracy we trust: social and economic determinants of support for democratic procedures in Central and Eastern Europe. Journal of Socio-Economics, 28: 577-596.

Loury, G.C., 1977. A dynamic theory of racial income differences. In P.A. Wallace and A. M. La Mond (Eds.) Women, minorities, and employment discrimination, pp. 153-86, Lexington, 
MA: Heath Publishers.

Narayan, D. and Pritchett, L., 1999. Cents and sociability: household income and social capital in rural Tanzania. Economic Development and Social Change, 47(4): 871-97.

North, D.C., 1990. Institutions, institutional change and economic performance, Cambridge: Cambridge University Press.

Olson, M., 1982. The rise and decline of nations. New Haven, CT: Yale University Press.

Paldam, M. and Svedsen, G.T., 2000. An essay on social capital: Looking for the fire behind the smoke. European Journal of Political Economy, 16(2): 339-366.

Paldam, M. and Svendsen, G.T., 2001. Missing social capital and the transition in Eastern Europe. Journal for Institutional Innovation, Development and Transition 5: 21-33.

Paldam, M., 2002. Social Capital and Sustainability. I Kochendorfer-Lucius, G. and Pleskovic, B., red: Dynamic Development in a Sustainable World. Transformation in Quality of Life, Growth and Institutions. Villa Borsig Workshop Series 2001. Published by: Development Policy Forum of the German Foundation for International Development (DSE) and the World Bank as well as the Federal Ministry for Economic Co-operation and Development (BMZ).

Pejovich, S.S., 2003. Understanding the transaction costs of transition: It's the culture, stupid, The Review of Austrian Economics, 16 (4): 347-361.

Portes, Alejandro, 1998. Social capital: Its origins and applications in modern Sociology. Annual Review of Sociology, 24: 1-24.

Putnam, R.D., 1993. Making Democracy Work: Civic Traditions in Modern Italy, with Robert Leonardi and Raffaella Y. Nanetti, Princeton University Press, Princeton, NJ.

Putnam, R., 2001. Social Capital: Measurement and Consequences. Canadian Journal of Policy Research, 2 (1): 41-51.

Raiser, M., 1999. Trust in transition, EBRD Working paper No. 39, EBRD, London, United Kingdom

Rodrik, D., 1999. Where Did All the Growth Go? External Shocks, Social Conflict and Growth Collapses. Journal of Economic Growth, 4 (4): 385 - 412.

Rose, R., 2000. Getting things done in an anti-modern society: Social capital networks in Russia, in Dasgupta, Partha and Ismail Serageldin, eds., Social Capital: A Multifaceted Perspective, pp. 147-172, The World Bank, Washington.

Stiglitz, J.E., 2000. Formal and informal institutions, in Dasgupta, Partha and Ismail Serageldin, eds., Social Capital: A Multifaceted Perspective, pp. 59-71, The World Bank, Washington.

Stoloff, J.A., Glanville, J.L., and Bienenstock, E.J., 1999. Women’s participation in the labor force: the role of social networks. Social Networks, 21: 91-108

The World Bank, 2002. Social Capital for Development. Available at http://www.worldbank.org/poverty/scapital/index.htm.

Uslaner, E., 1996. "Faith, Hope, and Charity: Social Capital, Trust, and Collective Action", mimeo, University of Maryland, College Park.

WZB, 2003, Quality of Life in the European Union and the Candidate Countries: Technical Report, Social Science Research Center Berlin (Wissenschaftszentrum Berlin), mimeo. 
Table 1: Alternative measures of social capital

\begin{tabular}{|c|c|c|c|c|c|c|c|c|}
\hline \multicolumn{2}{|c|}{ Average Participation } & \multicolumn{2}{|l|}{ Olson Groups } & \multicolumn{2}{|l|}{ Putnam Groups } & \multirow{2}{*}{$\begin{array}{l}\text { Trust } \\
\text { Sweden }\end{array}$} & \multirow{2}{*}{$\begin{array}{r}\text { WVS90 } \\
66.10\end{array}$} & \multirow{2}{*}{$\begin{array}{r}\text { WVS96 } \\
56.59\end{array}$} \\
\hline Sweden & 2.00 & Sweden & 1.00 & Netherlands & 1.08 & & & \\
\hline Denmark & 1.78 & Denmark & 0.79 & Sweden & 1.00 & Finland & 62.72 & 47.92 \\
\hline Netherlands & 1.70 & Netherlands & 0.62 & Denmark & 0.99 & Denmark & 57.66 & \\
\hline Finland & 1.24 & Finland & 0.44 & N. Ireland & 0.81 & Netherlands & 53.47 & \\
\hline Luxembourg & 1.03 & Luxembourg & 0.34 & Finland & 0.80 & Ireland & 47.37 & \\
\hline Czech Rep. & 0.94 & EU Average & 0.28 & Ireland & 0.74 & Great Britain & 43.68 & 29.09 \\
\hline Germany West & 0.93 & Austria & 0.25 & Germany West & 0.73 & N. Ireland & 43.62 & \\
\hline EU Average & 0.91 & Great Britain & 0.22 & Czech Rep. & 0.73 & EU Average & 41.16 & 37.74 \\
\hline N. Ireland & 0.90 & Czech Rep. & 0.21 & Luxembourg & 0.69 & Germany West & 37.86 & 39.92 \\
\hline Great Britain & 0.88 & Slovakia & 0.20 & Great Britain & 0.67 & Italy & 35.30 & \\
\hline Austria & 0.88 & Cyprus & 0.20 & Slovakia & 0.66 & Poland & 34.51 & 16.91 \\
\hline Slovakia & 0.86 & Germany West & 0.19 & EU Average & 0.64 & Spain & 34.24 & 28.65 \\
\hline Ireland & 0.84 & Belgium & 0.17 & Austria & 0.63 & Belgium & 33.50 & \\
\hline Belgium & 0.73 & Turkey & 0.15 & Malta & 0.57 & Austria & 31.82 & \\
\hline Cyprus & 0.72 & Slovenia & 0.14 & Slovenia & 0.56 & Lithuania & 30.80 & 21.31 \\
\hline Slovenia & 0.70 & Malta & 0.13 & Belgium & 0.56 & Bulgaria & 30.40 & 23.69 \\
\hline Malta & 0.69 & CC Average & 0.12 & Cyprus & 0.53 & Czech Rep. & 30.25 & \\
\hline France & 0.58 & Germany East & 0.12 & Estonia & 0.48 & Estonia & 27.58 & 21.06 \\
\hline Estonia & 0.57 & France & 0.10 & France & 0.48 & Germany East & 25.60 & 24.28 \\
\hline CC Average & 0.55 & Hungary & 0.10 & CC Average & 0.42 & Hungary & 24.59 & \\
\hline Germany East & 0.54 & Estonia & 0.10 & Germany East & 0.42 & CC Average & 23.96 & 18.28 \\
\hline Italy & 0.49 & Ireland & 0.10 & Italy & 0.40 & Slovakia & 23.01 & \\
\hline Lithuania & 0.48 & N. Ireland & 0.10 & Lithuania & 0.39 & France & 22.79 & \\
\hline Latvia & 0.47 & Italy & 0.09 & Latvia & 0.38 & Portugal & 21.67 & \\
\hline Turkey & 0.43 & Latvia & 0.09 & Hungary & 0.30 & Latvia & 19.05 & 23.92 \\
\hline Hungary & 0.40 & Lithuania & 0.09 & Spain & 0.29 & Slovenia & 17.39 & 15.54 \\
\hline Poland & 0.35 & Romania & 0.08 & Portugal & 0.29 & Romania & 16.07 & \\
\hline Spain & 0.35 & Poland & 0.07 & Poland & 0.28 & Turkey & 9.98 & 5.50 \\
\hline Portugal & 0.34 & Spain & 0.06 & Turkey & 0.28 & Cyprus & & \\
\hline Greece & 0.31 & Greece & 0.05 & Greece & 0.26 & Greece & & \\
\hline Romania & 0.29 & Portugal & 0.05 & Romania & 0.21 & Luxembourg & & \\
\hline Bulgaria & 0.18 & Bulgaria & 0.05 & Bulgaria & 0.13 & Malta & & \\
\hline
\end{tabular}


Table 1 (continued)

\begin{tabular}{|c|c|c|c|c|c|c|c|c|c|}
\hline \multicolumn{2}{|c|}{ Network: Depressed } & \multicolumn{2}{|l|}{ Network: Job } & \multicolumn{2}{|c|}{ Network: Money } & \multicolumn{2}{|c|}{ Altruism: Money } & \multicolumn{2}{|l|}{ Altruism: Time } \\
\hline Ireland & 0.93 & Ireland & 0.86 & Ireland & 0.91 & N. Ireland & 1.29 & Romania & 0.67 \\
\hline Netherlands & 0.92 & Spain & 0.80 & Spain & 0.91 & Malta & 1.22 & Cyprus & 0.64 \\
\hline Spain & 0.92 & Netherlands & 0.79 & Sweden & 0.90 & Ireland & 1.17 & Luxembourg & 0.56 \\
\hline Sweden & 0.91 & Luxembourg & 0.74 & Netherlands & 0.88 & Netherlands & 1.09 & Finland & 0.55 \\
\hline Denmark & 0.90 & Denmark & 0.74 & Denmark & 0.87 & Romania & 1.08 & Netherlands & 0.54 \\
\hline Slovakia & 0.90 & Austria & 0.74 & N. Ireland & 0.85 & Cyprus & 0.93 & Ireland & 0.51 \\
\hline N. Ireland & 0.89 & N. Ireland & 0.74 & Finland & 0.84 & Luxembourg & 0.93 & Slovenia & 0.50 \\
\hline Great Britain & 0.88 & Portugal & 0.73 & Italy & 0.82 & Great Britain & 0.92 & Turkey & 0.49 \\
\hline France & 0.87 & Great Britain & 0.72 & Czech Rep. & 0.80 & Italy & 0.92 & Austria & 0.49 \\
\hline Czech Rep. & 0.86 & Slovenia & 0.72 & EU Average & 0.80 & Poland & 0.89 & Hungary & 0.43 \\
\hline EU Average & 0.86 & Italy & 0.70 & France & 0.79 & Lithuania & 0.89 & N. Ireland & 0.42 \\
\hline Luxembourg & 0.86 & EU Average & 0.70 & Slovakia & 0.79 & Spain & 0.87 & Poland & 0.40 \\
\hline Italy & 0.85 & France & 0.69 & Slovenia & 0.79 & EU Average & 0.84 & EU Average & 0.40 \\
\hline Austria & 0.84 & Sweden & 0.66 & Great Britain & 0.79 & Turkey & 0.82 & Italy & 0.39 \\
\hline Malta & 0.84 & Belgium & 0.65 & Luxembourg & 0.78 & Greece & 0.82 & Greece & 0.38 \\
\hline Portugal & 0.84 & Hungary & 0.63 & Estonia & 0.77 & Austria & 0.78 & Malta & 0.38 \\
\hline Poland & 0.83 & Finland & 0.61 & Poland & 0.76 & France & 0.75 & Portugal & 0.37 \\
\hline Belgium & 0.81 & Germany West & 0.61 & Austria & 0.76 & Sweden & 0.74 & Lithuania & 0.35 \\
\hline Germany West & 0.80 & Cyprus & 0.59 & Hungary & 0.73 & CC Average & 0.73 & Latvia & 0.34 \\
\hline Hungary & 0.80 & Greece & 0.56 & Greece & 0.70 & Denmark & 0.72 & Belgium & 0.33 \\
\hline Slovenia & 0.78 & Germany East & 0.54 & CC Average & 0.70 & Slovenia & 0.70 & Spain & 0.33 \\
\hline Germany East & 0.78 & Poland & 0.53 & Lithuania & 0.68 & Portugal & 0.66 & Great Britain & 0.32 \\
\hline CC Average & 0.78 & CC Average & 0.53 & Romania & 0.68 & Belgium & 0.65 & Germany East & 0.32 \\
\hline Estonia & 0.77 & Slovakia & 0.51 & Germany West & 0.68 & Hungary & 0.65 & Denmark & 0.31 \\
\hline Lithuania & 0.77 & Lithuania & 0.50 & Bulgaria & 0.67 & Germany East & 0.60 & Germany West & 0.31 \\
\hline Romania & 0.73 & Malta & 0.50 & Belgium & 0.66 & Latvia & 0.59 & France & 0.30 \\
\hline Turkey & 0.71 & Estonia & 0.49 & Cyprus & 0.65 & Germany West & 0.57 & Sweden & 0.30 \\
\hline Latvia & 0.71 & Turkey & 0.48 & Germany East & 0.62 & Slovakia & 0.52 & Slovakia & 0.26 \\
\hline Cyprus & 0.70 & Latvia & 0.40 & Turkey & 0.58 & Estonia & 0.41 & Czech Rep. & 0.20 \\
\hline Greece & 0.69 & Bulgaria & 0.37 & Malta & 0.56 & Bulgaria & 0.32 & Bulgaria & 0.16 \\
\hline
\end{tabular}




\section{Notes:}

Average participation is the average number of voluntary organizations in which respondents actively participate. Putnam groups are charities, religious organizations, cultural or artistic organizations, youth organizations, sports clubs and associations, hobby clubs, and other clubs or organizations. Olsonian groups are trade unions or political parties, human rights movements or organizations, organizations for the protections of nature, animals and the environment, and consumer organizations. The maximum possible value is 11 for average participation, 7 for Putnam groups and 4 for Olson groups. Network variables take the value of one if the respondents feel she has someone (besides the members of her immediate household) to rely on when feeling depressed, in need of a new job for herself or a family member, or to borrow money urgently, and zero otherwise. Altruism variables measure whether the respondent contributed money or gave up some of her time during the preceding 12 months to help poor or socially excluded people. It takes values of 0 (never), 1 (less than once a month) and 2 (more than once a month). These variables are based on the following surveys: EB50.1 (1998) for average participation, EB56.1 (2001) for networks, EB52.1 for altruism, and CCEB 2002.1 for all three types of variables for the candidate countries. See the text for further details and the precise wording of the relevant questions. We are grateful to the Gallup Organisation Europe for kindly making these data available to us.

Trust is based on the World Value Surveys rounds of 1990 and 1996-97. The numbers correspond to the fraction of the respondents who declare that most people can be trusted. Blank cell indicates that the country did not participate in that survey round and therefore no data are available. 
Table 2: Correlation matrix with alternative measures of social capital

\begin{tabular}{|c|c|c|c|c|c|c|c|c|c|}
\hline & $\begin{array}{r}\text { Average } \\
\text { Participation }\end{array}$ & $\begin{array}{l}\text { Olson } \\
\text { Groups }\end{array}$ & $\begin{array}{l}\text { Putnam } \\
\text { Groups }\end{array}$ & $\begin{array}{l}\text { Network: } \\
\text { Depressed }\end{array}$ & $\begin{array}{r}\text { Network: } \\
\text { Job }\end{array}$ & $\begin{array}{r}\text { Network: } \\
\text { Money }\end{array}$ & $\begin{array}{r}\text { Altruism: } \\
\text { Money }\end{array}$ & $\begin{array}{r}\text { Altruism: } \\
\text { Time }\end{array}$ & $\begin{array}{r}\text { Trust } \\
\text { (WVS90) }\end{array}$ \\
\hline Olson Groups & 0.937 & & & & & & & & \\
\hline Putnam Groups & 0.949 & 0.779 & & & & & & & \\
\hline Network: Depressed & 0.594 & 0.443 & 0.665 & & & & & & \\
\hline Network: Job & 0.451 & 0.297 & 0.543 & 0.753 & & & & & \\
\hline Network: Money & 0.529 & 0.452 & 0.539 & 0.792 & 0.742 & & & & \\
\hline Altruism: Money & 0.145 & 0.039 & 0.228 & 0.295 & 0.373 & 0.167 & & & \\
\hline Altruism: Time & 0.059 & 0.047 & 0.067 & -0.108 & 0.204 & -0.022 & 0.649 & & \\
\hline Trust (WVS90) & 0.804 & 0.748 & 0.767 & 0.653 & 0.463 & 0.671 & 0.309 & 0.014 & \\
\hline Trust (WVS96) & 0.836 & 0.790 & 0.805 & 0.624 & 0.344 & 0.566 & 0.038 & -0.088 & 0.915 \\
\hline
\end{tabular}


Table 3: Individual determinants of civic participation in candidate countries

\begin{tabular}{|c|c|c|c|c|c|c|}
\hline & \begin{tabular}{|l|} 
Overall Civic \\
Participation \\
\end{tabular} & std. error & $\begin{array}{r}\text { Putnam } \\
\text { Groups }\end{array}$ & std. error & $\begin{array}{c}\text { Olsonian } \\
\text { Groups }\end{array}$ & std. error \\
\hline Female & $-0.275^{* * *}$ & $(0.049)$ & $-0.258 * * *$ & $(0.052)$ & $-0.200 * * *$ & $\overline{(0.073)}$ \\
\hline Married & $-0.131 * *$ & (0.059) & $-0.173 * * *$ & $(0.063)$ & 0.082 & $(0.091)$ \\
\hline Age & 0.013 & $(0.010)$ & -0.011 & $(0.010)$ & $0.086 * * *$ & $(0.017)$ \\
\hline Age squared & -0.0001 & $(0.0001)$ & 0.0001 & $(0.0001)$ & $-0.0007 * * *$ & $(0.0002)$ \\
\hline Children & -0.022 & $(0.025)$ & -0.022 & $(0.027)$ & -0.038 & (0.039) \\
\hline HH Size & -0.030 & $(0.024)$ & -0.019 & $(0.026)$ & -0.060 & $(0.037)$ \\
\hline Secondary & $0.297 * * *$ & $(0.081)$ & $0.286 * * *$ & $(0.087)$ & $0.426 * * *$ & $(0.141)$ \\
\hline University & $0.763 * * *$ & $(0.090)$ & $0.717 * * *$ & $(0.096)$ & $0.873^{* * *}$ & $(0.149)$ \\
\hline Student & $1.225^{* * *}$ & $(0.139)$ & $1.355^{* * *}$ & $(0.145)$ & $0.668 * * *$ & $(0.245)$ \\
\hline Self-employed & $0.214^{*}$ & $(0.116)$ & $0.404 * * *$ & $(0.121)$ & -0.077 & $(0.155)$ \\
\hline White collar & $0.123 *$ & $(0.075)$ & $0.190 * *$ & $(0.080)$ & 0.050 & (0.099) \\
\hline House person & $-0.439 * * *$ & $(0.117)$ & -0.146 & $(0.122)$ & $-1.177 * * *$ & (0.229) \\
\hline Unemployed & $-0.424 * * *$ & $(0.114)$ & $-0.296 * *$ & $(0.123)$ & $-0.613 * * *$ & $(0.185)$ \\
\hline Retiree & $-0.358 * * *$ & $(0.095)$ & 0.018 & $(0.100)$ & $-1.050 * * *$ & $(0.149)$ \\
\hline Farmer/fisherman & -0.191 & $(0.206)$ & 0.023 & $(0.230)$ & -0.329 & $(0.311)$ \\
\hline UE History: 1 & $-0.359 * * *$ & $(0.083)$ & $-0.303^{* * *}$ & $(0.088)$ & $-0.297 * *$ & $(0.124)$ \\
\hline UE History: 2+ & $-0.258 * *$ & $(0.107)$ & -0.137 & $(0.111)$ & $-0.446 * * *$ & $(0.180)$ \\
\hline HH Income 2nd Quartile & 0.103 & $(0.080)$ & 0.077 & $(0.085)$ & 0.186 & $(0.131)$ \\
\hline HH Income 3rd Quartile & $0.313^{* * *}$ & $(0.082)$ & $0.254 * * *$ & $(0.087)$ & $0.315^{* *}$ & $(0.132)$ \\
\hline HH Income 4th Quartile & $0.378 * * *$ & $(0.089)$ & $0.359 * * *$ & $(0.094)$ & $0.263 *$ & $(0.143)$ \\
\hline Small/Medium town & -0.093 & $(0.058)$ & $-0.132 * *$ & $(0.061)$ & -0.003 & $(0.086)$ \\
\hline City & $-0.350 * * *$ & $(0.064)$ & $-0.347 * * *$ & $(0.068)$ & $-0.258 * * *$ & $(0.098)$ \\
\hline Cyprus & $1.632 * * *$ & $(0.149)$ & $1.881^{* * *}$ & $(0.166)$ & $1.104 * * *$ & $(0.212)$ \\
\hline Czech Rep. & $1.924 * * *$ & $(0.131)$ & $2.141 * * *$ & $(0.150)$ & $1.185^{* * *}$ & $(0.185)$ \\
\hline Estonia & $1.124 * * *$ & $(0.130)$ & $1.425^{* * *}$ & $(0.150)$ & 0.312 & $(0.196)$ \\
\hline Hungary & $0.998 * * *$ & $(0.130)$ & $1.168 * * *$ & $(0.150)$ & $0.680 * * *$ & $(0.186)$ \\
\hline Latvia & $1.044 * * *$ & $(0.127)$ & $1.317 * * *$ & $(0.149)$ & $0.330 *$ & $(0.196)$ \\
\hline Lithuania & $1.100 * * *$ & $(0.133)$ & $1.392 * * *$ & $(0.154)$ & 0.128 & $(0.210)$ \\
\hline Malta & $1.605^{* * *}$ & $(0.163)$ & $1.968 * * *$ & $(0.178)$ & $0.874 * * *$ & $(0.244)$ \\
\hline Poland & $0.522 * * *$ & $(0.123)$ & $0.748 * * *$ & $(0.145)$ & 0.164 & $(0.185)$ \\
\hline Romania & $0.425 * * *$ & $(0.134)$ & $0.531 * * *$ & $(0.160)$ & 0.230 & (0.198) \\
\hline Slovakia & $2.047 * * *$ & $(0.127)$ & $2.276^{* * *}$ & $(0.145)$ & $1.296 * * *$ & $(0.182)$ \\
\hline Slovenia & $1.501 * * *$ & $(0.126)$ & $1.704^{* * *}$ & $(0.147)$ & $0.800 * * *$ & $(0.186)$ \\
\hline Log likelihood & $-7,596.218$ & & $-6,625.982$ & & -3273.130 & \\
\hline Pseudo R2 & 0.080 & & 0.084 & & 0.082 & \\
\hline Wald $\chi^{2}$ & $1224.67 * * *$ & & $1,093.05^{* * *}$ & & $562.47 * * *$ & \\
\hline No. of observations & 8,899 & & 8,901 & & 8,899 & \\
\hline
\end{tabular}

Notes: Estimated with ordered logit; Significance levels: $* * * 1 \%$, $* * 5 \%$ and $* 10 \%$. Civic participation is measured as active participation in voluntary organizations (see the text for precise wording of the question and list of organizations). Putnam groups are charities, religious organizations, cultural or artistic organizations, youth organizations, sports clubs and associations, hobby clubs, and other clubs or organizations. Olsonian groups are trade unions or political parties, human rights movements or organizations, organizations for the protections of nature, animals and the environment, and consumer organizations. 
Table 4: Individual determinants of civic participation in member states

\begin{tabular}{|c|c|c|c|c|c|c|}
\hline & \begin{tabular}{|l|} 
Overall Civic \\
Participation \\
\end{tabular} & std. error & $\begin{array}{l}\text { Putnam } \\
\text { Groups }\end{array}$ & std. error & $\begin{array}{c}\text { Olsonian } \\
\text { Groups }\end{array}$ & std. error \\
\hline Female & $-0.242 * * *$ & $(0.041)$ & $-0.215^{* * *}$ & $(0.042)$ & $-0.166 * * *$ & $(0.054)$ \\
\hline Married & 0.020 & $(0.050)$ & -0.022 & $(0.050)$ & $0.228 * * *$ & $(0.070)$ \\
\hline Age & $0.041 * * *$ & $(0.007)$ & $0.022 * * *$ & $(0.008)$ & $0.081^{* * *}$ & $(0.012)$ \\
\hline Age squared & $-0.0004 * * *$ & $(0.0001)$ & $-0.0002 * *$ & $(0.0001)$ & $-0.0008 * * *$ & $(0.0001)$ \\
\hline Children & -0.031 & $(0.031)$ & $-0.071 * *$ & $(0.032)$ & $0.120^{* * *}$ & $(0.044)$ \\
\hline HH Size & 0.027 & $(0.022)$ & $0.074^{* * *}$ & $(0.023)$ & $-0.159 * * *$ & $(0.035)$ \\
\hline Secondary & $0.291 * * *$ & $(0.057)$ & $0.261^{* * *}$ & (0.059) & $0.328 * * *$ & $(0.082)$ \\
\hline University & $0.837 * * *$ & $(0.064)$ & $0.728^{* * *}$ & $(0.067)$ & $0.789 * * *$ & $(0.088)$ \\
\hline Student & $1.015 * * *$ & $(0.098)$ & $1.153^{* * *}$ & $(0.104)$ & $0.355^{* * *}$ & $(0.143)$ \\
\hline Self-employed & -0.140 & $(0.090)$ & 0.120 & $(0.089)$ & $-0.649 * * *$ & (0.123) \\
\hline White collar & 0.090 & $(0.059)$ & $0.116^{*}$ & $(0.061)$ & -0.037 & $(0.074)$ \\
\hline House person & $-0.199 * * *$ & $(0.080)$ & 0.034 & $(0.081)$ & $-0.690 * * *$ & (0.113) \\
\hline Unemployed & $-0.165^{*}$ & $(0.090)$ & -0.020 & $(0.092)$ & $-0.332 * * *$ & $(0.123)$ \\
\hline Retiree & -0.095 & $(0.081)$ & $0.164^{*}$ & $(0.085)$ & $-0.521 * * *$ & $(0.112)$ \\
\hline Farmer/fisherman & $0.291 * *$ & $(0.150)$ & $0.407 * * *$ & $(0.163)$ & 0.096 & $(0.217)$ \\
\hline HH Income 2nd Quartile & $0.249 * * *$ & $(0.060)$ & $0.195^{* * *}$ & $(0.062)$ & $0.269 * * *$ & $(0.084)$ \\
\hline HH Income 3rd Quartile & $0.649 * * *$ & $(0.064)$ & $0.551^{* * *}$ & $(0.065)$ & $0.644 * * *$ & $(0.091)$ \\
\hline HH Income 4th Quartile & $0.756^{* * *}$ & $(0.069)$ & $0.636^{* * *}$ & $(0.071)$ & $0.723^{* * *}$ & $(0.098)$ \\
\hline Denmark & $1.716^{* * *}$ & $(0.110)$ & $0.952^{* * *}$ & $(0.113)$ & $1.991^{* * *}$ & $(0.149)$ \\
\hline Germany West & $0.552 * * *$ & $(0.112)$ & $0.645^{* * *}$ & $(0.113)$ & 0.109 & $(0.165)$ \\
\hline Greece & $-0.979 * * *$ & $(0.124)$ & $-0.914 * * *$ & $(0.127)$ & $-0.933 * * *$ & $(0.208)$ \\
\hline Italy & $-0.415^{* * *}$ & $(0.129)$ & $-0.361 * * *$ & $(0.131)$ & $-0.409 * *$ & $(0.206)$ \\
\hline Spain & $-0.697 * * *$ & $(0.134)$ & $-0.681 * * *$ & $(0.138)$ & $-0.722 * * *$ & $(0.226)$ \\
\hline France & $-0.285 * * *$ & $(0.115)$ & -0.173 & $(0.118)$ & $-0.584 * * *$ & $(0.182)$ \\
\hline Ireland & $0.520 * * *$ & $(0.131)$ & $0.657 * * *$ & $(0.135)$ & -0.126 & $(0.207)$ \\
\hline N-Ireland & $0.501^{* * *}$ & $(0.177)$ & $0.637 * * *$ & $(0.182)$ & -0.233 & $(0.273)$ \\
\hline Luxembourg & $0.747 * * *$ & $(0.152)$ & $0.537 * * *$ & $(0.146)$ & $0.929 * * *$ & $(0.215)$ \\
\hline Netherlands & $1.753 * * *$ & $(0.112)$ & $1.307 * * *$ & $(0.113)$ & $1.753 * * *$ & $(0.154)$ \\
\hline Portugal & $-0.688 * * *$ & $(0.128)$ & $-0.602 * * *$ & $(0.132)$ & $-0.950 * * *$ & $(0.221)$ \\
\hline Great Britain & $0.817 * * *$ & $(0.123)$ & $0.736 * * *$ & $(0.124)$ & $0.665^{* * *}$ & $(0.170)$ \\
\hline Germany East & $-0.202 *$ & $(0.113)$ & -0.131 & $(0.116)$ & $-0.457 * * *$ & $(0.177)$ \\
\hline Finland & $1.143 * * *$ & $(0.108)$ & $0.702^{* * *}$ & $(0.112)$ & $1.455^{* * *}$ & (0.149) \\
\hline Sweden & $2.073 * * *$ & $(0.143)$ & $0.984^{* * *}$ & $(0.150)$ & $2.620^{* * *}$ & $(0.184)$ \\
\hline Austria & $0.478 * * *$ & $(0.119)$ & $0.408^{* * *}$ & $(0.119)$ & $0.513^{* * *}$ & $(0.168)$ \\
\hline Log likelihood & $-1,1367.22$ & & $-10,210.34$ & & $-5,870.042$ & \\
\hline Pseudo R2 & 0.127 & & 0.081 & & 0.198 & \\
\hline Wald $\chi^{2}$ & $2,923.19 * * *$ & & $1,568.99 * * *$ & & $2,273.74$ & \\
\hline No. of observations & 10,699 & & 10,699 & & 10,699 & \\
\hline
\end{tabular}

Notes: Estimated with ordered logit; Significance levels: *** $1 \%$, ** 5\% and * $10 \%$. Civic participation is measured as active participation in voluntary organizations (see the text for precise wording of the question and list of organizations). Putnam groups are charities, religious organizations, cultural or artistic organizations, youth organizations, sports clubs and associations, hobby clubs, and other clubs or organizations. Olsonian groups are trade unions or political parties, human rights movements or organizations, organizations for the protections of nature, animals and the environment, and consumer organizations. 
Table 5: Individual determinants of social networks in candidate countries

\begin{tabular}{|c|c|c|c|c|c|c|}
\hline & $\begin{array}{c}\text { Networks if } \\
\text { depressed }\end{array}$ & std. error & $\begin{array}{c}\text { Networks if } \\
\text { needs job }\end{array}$ & std. error & $\begin{array}{c}\begin{array}{c}\text { Networks to } \\
\text { borrow }\end{array} \\
\end{array}$ & std. error \\
\hline Female & $0.343^{* * *}$ & $(0.057)$ & $-0.119 * *$ & $(0.050)$ & 0.081 & $\overline{(0.053)}$ \\
\hline Married & 0.096 & $(0.070)$ & 0.062 & $(0.062)$ & $0.127 *$ & $(0.066)$ \\
\hline Age & $-0.059 * * *$ & $(0.011)$ & $-0.065 * * *$ & $(0.010)$ & $-0.071 * * *$ & $(0.010)$ \\
\hline Age squared & $0.0004 * * *$ & -0.0001 & $0.0005 * * *$ & -0.0001 & $0.0006 * * *$ & -0.0001 \\
\hline Children & 0.042 & $(0.027)$ & 0.026 & $(0.025)$ & $0.086 * * *$ & $(0.026)$ \\
\hline HH Size & $-0.156 * * *$ & $(0.027)$ & $-0.148 * * *$ & $(0.024)$ & $-0.181 * * *$ & $(0.025)$ \\
\hline Secondary & $0.091 * * *$ & $(0.079)$ & $0.122 *$ & $(0.075)$ & $0.298 * * *$ & $(0.074)$ \\
\hline University & $0.275^{* *}$ & $(0.092)$ & $0.349 * * *$ & $(0.086)$ & $0.459 * * *$ & $(0.087)$ \\
\hline Student & $0.385^{* *}$ & $(0.172)$ & $0.258 *$ & $(0.146)$ & 0.235 & $(0.157)$ \\
\hline Self-employed & 0.344 & (0.159) & $0.486 * * *$ & $(0.130)$ & $0.636 * * *$ & $(0.161)$ \\
\hline White collar & 0.098 & $(0.094)$ & $0.217 * * *$ & $(0.078)$ & $0.147 *$ & $(0.088)$ \\
\hline House person & -0.084 & $(0.120)$ & $-0.203^{*}$ & (0.109) & 0.011 & $(0.114)$ \\
\hline Unemployed & -0.083 & $(0.113)$ & $-0.255^{* * *}$ & $(0.104)$ & -0.084 & $(0.106)$ \\
\hline Retiree & 0.044 & $(0.106)$ & -0.052 & (0.095) & -0.093 & $(0.100)$ \\
\hline Farmer/fisherman & -0.234 & $(0.224)$ & 0.193 & (0.197) & -0.089 & $(0.213)$ \\
\hline UE History: 1 & $-0.169 * *$ & $(0.088)$ & $-0.320 * * *$ & $(0.077)$ & $-0.215^{* * *}$ & $(0.084)$ \\
\hline UE History: 2+ & $-0.329 * * *$ & $(0.117)$ & $-0.296 * * *$ & (0.104) & $-0.438 * * *$ & $(0.108)$ \\
\hline HH Income 2nd Quartile & $0.244 * * *$ & $(0.082)$ & $0.278 * * *$ & $(0.079)$ & $0.240 * * *$ & $(0.078)$ \\
\hline HH Income 3rd Quartile & $0.362 * * *$ & $(0.087)$ & $0.399 * * *$ & $(0.081)$ & $0.420 * * *$ & $(0.082)$ \\
\hline HH Income 4th Quartile & $0.621^{* * *}$ & $(0.098)$ & $0.866^{* * *}$ & $(0.089)$ & $0.749 * * *$ & $(0.094)$ \\
\hline Small/Medium town & -0.064 & $(0.067)$ & $-0.122 * *$ & $(0.060)$ & $-0.141 * *$ & $(0.063)$ \\
\hline City & -0.046 & $(0.073)$ & -0.055 & $(0.066)$ & $-0.239 * * *$ & $(0.069)$ \\
\hline Cyprus & -0.213 & $(0.138)$ & $0.814^{* * *}$ & $(0.136)$ & $-0.312 * *$ & $(0.136)$ \\
\hline Czech Rep. & $0.815^{* * *}$ & $(0.147)$ & $1.025 * * *$ & $(0.129)$ & $0.339 * * *$ & $(0.137)$ \\
\hline Estonia & 0.030 & $(0.123)$ & 0.154 & $(0.115)$ & 0.162 & $(0.122)$ \\
\hline Hungary & $0.392 * * *$ & $(0.121)$ & $1.072^{* * *}$ & $(0.112)$ & 0.145 & $(0.116)$ \\
\hline Latvia & -0.191 & $(0.119)$ & -0.113 & $(0.115)$ & $-0.536^{* * *}$ & $(0.114)$ \\
\hline Lithuania & -0.003 & $(0.131)$ & $0.251^{* *}$ & $(0.123)$ & $-0.361^{* * *}$ & $(0.125)$ \\
\hline Malta & $0.750 * * *$ & $(0.173)$ & $0.370 * *$ & $(0.154)$ & $-0.609 * * *$ & $(0.151)$ \\
\hline Poland & $0.629 * * *$ & $(0.112)$ & $0.452 * * *$ & $(0.100)$ & $0.285^{* * *}$ & (0.105) \\
\hline Romania & -0.087 & $(0.115)$ & $0.233^{* *}$ & $(0.113)$ & $-0.189 *$ & $(0.112)$ \\
\hline Slovakia & $1.209 * * *$ & $(0.154)$ & $0.528^{* * *}$ & $(0.118)$ & $0.447^{* * *}$ & $(0.128)$ \\
\hline Slovenia & 0.150 & $(0.128)$ & $1.258 * * *$ & $(0.121)$ & $0.221 *$ & $(0.126)$ \\
\hline Constant & $2.470 * * *$ & $(0.299)$ & $1.386 * * *$ & $(0.267)$ & $2.648^{* * *}$ & $(0.285)$ \\
\hline Log likelihood & $-4,259.41$ & & $-4,938.50$ & & $-4,646.19$ & \\
\hline Pseudo R2 & 0.055 & & 0.092 & & 0.057 & \\
\hline Wald $\chi^{2}$ & $458.86^{* * *}$ & & $859.85^{* * *}$ & & $522.32 * * *$ & \\
\hline No. of observations & 8,625 & & 7,852 & & 8,303 & \\
\hline
\end{tabular}

Notes: Estimated with ordered logit; Significance levels: *** $1 \%$, ** $5 \%$ and $* 10 \%$. Networks variables take value 1 if the respondent can rely on other people outside their immediate household if she feels depressed, needs a job for herself or a family member, or needs to borrow money to pay an urgent bill. 
Table 6: Individual determinants of social networks in member states

\begin{tabular}{|c|c|c|c|c|c|c|}
\hline & $\begin{array}{c}\text { Networks if } \\
\text { depressed }\end{array}$ & std. error & $\begin{array}{l}\text { Networks if } \\
\text { needs job }\end{array}$ & std. error & $\begin{array}{l}\text { Networks to } \\
\text { borrow }\end{array}$ & std. error \\
\hline Female & $0.557 * * *$ & $(0.062)$ & -0.043 & $(0.049)$ & $0.191^{* * *}$ & $(0.056)$ \\
\hline Married & -0.052 & $(0.068)$ & 0.046 & $(0.055)$ & -0.003 & $(0.062)$ \\
\hline Age & $-0.027 * * *$ & $(0.011)$ & $-0.039 * * *$ & (0.009) & $-0.025 * * *$ & $(0.010)$ \\
\hline Age squared & 0.0001 & $(0.0001)$ & $0.0002 * * *$ & $(0.0001)$ & 0.0001 & $(0.0001)$ \\
\hline Secondary & $0.213^{* * *}$ & $(0.076)$ & $0.172^{* * *}$ & $(0.063)$ & 0.093 & $(0.070)$ \\
\hline University & $0.396 * * *$ & $(0.095)$ & $0.293^{* * *}$ & $(0.073)$ & $0.205^{* * *}$ & $(0.084)$ \\
\hline Student & $0.713^{* * *}$ & $(0.181)$ & $0.378 * * *$ & $(0.131)$ & $0.538 * * *$ & $(0.157)$ \\
\hline Self-employed & $0.257^{*}$ & $(0.146)$ & 0.105 & $(0.114)$ & $0.367 * * *$ & $(0.135)$ \\
\hline White collar & $0.303^{* * *}$ & $(0.100)$ & $0.124 *$ & $(0.075)$ & $0.268^{* * *}$ & (0.088) \\
\hline House person & 0.065 & $(0.124)$ & -0.082 & $(0.092)$ & 0.126 & $(0.107)$ \\
\hline Unemployed & $-0.272^{* *}$ & $(0.117)$ & $-0.732 * * *$ & $(0.094)$ & $-0.315^{* * *}$ & $(0.104)$ \\
\hline Retiree & 0.023 & $(0.115)$ & -0.115 & $(0.090)$ & -0.040 & $(0.105)$ \\
\hline Farmer/fisherman & $0.459 *$ & $(0.278)$ & -0.021 & $(0.215)$ & -0.003 & $(0.239)$ \\
\hline HH Income 2nd Quartile & $0.304 * * *$ & $(0.081)$ & $0.301 * * *$ & $(0.066)$ & $0.225^{* * *}$ & $(0.073)$ \\
\hline HH Income 3rd Quartile & $0.391^{* * *}$ & $(0.090)$ & $0.477 * * *$ & $(0.073)$ & $0.529 * * *$ & $(0.084)$ \\
\hline HH Income 4th Quartile & $0.548^{* * *}$ & $(0.104)$ & $0.615^{* * *}$ & $(0.080)$ & $0.652 * * *$ & $(0.093)$ \\
\hline Small/Medium town & -0.063 & $(0.070)$ & $-0.140 * * *$ & $(0.057)$ & -0.081 & $(0.064)$ \\
\hline City & 0.011 & $(0.077)$ & -0.021 & $(0.062)$ & 0.015 & $(0.070)$ \\
\hline Denmark & $0.695^{* * *}$ & $(0.162)$ & $0.217^{*}$ & $(0.130)$ & $1.314^{* * *}$ & $(0.144)$ \\
\hline Germany West & 0.084 & $(0.144)$ & $-0.212 *$ & $(0.126)$ & $0.264 * *$ & $(0.126)$ \\
\hline Greece & $-0.494 * * *$ & $(0.141)$ & $-0.376 * * *$ & $(0.129)$ & $0.345^{* * * *}$ & $(0.130)$ \\
\hline Italy & $0.293 *$ & $(0.162)$ & $0.256^{*}$ & $(0.144)$ & $0.957 * * *$ & $(0.152)$ \\
\hline Spain & $1.142 * * *$ & $(0.185)$ & $0.665 * * *$ & $(0.144)$ & $1.807 * * *$ & $(0.172)$ \\
\hline France & $0.606^{* * *}$ & $(0.160)$ & 0.165 & $(0.131)$ & $0.857 * * *$ & $(0.136)$ \\
\hline Ireland & $1.489 * * *$ & $(0.286)$ & $0.806 * * *$ & $(0.187)$ & $1.573^{* * *}$ & $(0.219)$ \\
\hline N-Ireland & $0.978^{* * *}$ & $(0.285)$ & 0.310 & $(0.204)$ & $1.344^{* * *}$ & $(0.243)$ \\
\hline Luxembourg & $0.447 * * *$ & $(0.182)$ & $0.348^{* *}$ & $(0.155)$ & $0.680^{* * *}$ & $(0.157)$ \\
\hline Netherlands & $1.228^{* * *}$ & $(0.200)$ & $0.510^{* * *}$ & $(0.145)$ & $1.628 * * *$ & $(0.175)$ \\
\hline Portugal & $0.316^{* *}$ & $(0.157)$ & $0.473 * * *$ & $(0.140)$ & $0.874 * * *$ & (0.143) \\
\hline Great Britain & $0.722 * * *$ & $(0.177)$ & $0.326^{* *}$ & $(0.143)$ & $0.959 * * *$ & $(0.150)$ \\
\hline Germany East & -0.024 & $(0.140)$ & $-0.394 * * *$ & $(0.124)$ & 0.068 & $(0.124)$ \\
\hline Finland & 0.232 & $(0.150)$ & $-0.317 * * *$ & $(0.127)$ & $1.156^{* * *}$ & $(0.140)$ \\
\hline Sweden & $1.079 * * *$ & $(0.167)$ & 0.020 & $(0.125)$ & $1.908 * * *$ & $(0.156)$ \\
\hline Austria & 0.062 & $(0.155)$ & $0.299 * *$ & $(0.141)$ & $0.486^{* * *}$ & $(0.140)$ \\
\hline Constant & $1.501 * * *$ & $(0.281)$ & $1.526 * * *$ & $(0.231)$ & $0.801 * * *$ & $(0.253)$ \\
\hline Log likelihood & $-4,001.45$ & & $-5,622.07$ & & $-4,612.88$ & \\
\hline Pseudo R2 & 0.080 & & 0.074 & & 0.091 & \\
\hline Wald $\chi^{2}$ & $626.11^{* * *}$ & & $788.80^{* * *}$ & & $808.76^{* * *}$ & \\
\hline No. of observations & 10,376 & & 9,650 & & 9,952 & \\
\hline
\end{tabular}

Notes: Estimated with ordered logit; Significance levels: $* * * 1 \%, * * 5 \%$ and $* 10 \%$. Networks variables take value 1 if the respondent can rely on other people outside their immediate household if she feels depressed, needs a job for herself or a family member, or needs to borrow money to pay an urgent bill. 
Table 7: Individual determinants of social capital: Pooled data

\begin{tabular}{|c|c|c|c|c|c|c|c|c|c|c|c|c|}
\hline & \begin{tabular}{|l|} 
Overall Civic \\
Participation \\
\end{tabular} & std. error & $\begin{array}{l}\text { Putnam } \\
\text { Groups }\end{array}$ & std. error & $\begin{array}{c}\text { Olsonian } \\
\text { Groups }\end{array}$ & std. error & $\begin{array}{c}\text { Networks if } \\
\text { depressed }\end{array}$ & std. error & $\begin{array}{c}\text { Networks if } \\
\text { needs job }\end{array}$ & std. error & $\begin{array}{l}\text { Networks } \\
\text { to borrow }\end{array}$ & std. error \\
\hline Female & $-0.240 * * *$ & $(0.030)$ & $-0.202 * * *$ & $(0.035)$ & $-0.145^{* * *}$ & $(0.041)$ & $0.421 * * *$ & $(0.040)$ & $-0.077 * * *$ & $(0.033)$ & $0.167 * * *$ & $(0.037)$ \\
\hline Married & $0.071^{* *}$ & $(0.036)$ & $0.111 * * *$ & $(0.042)$ & $0.336 * * *$ & $(0.052)$ & -0.055 & $(0.046)$ & -0.008 & $(0.038)$ & 0.016 & $(0.042)$ \\
\hline Age & $0.034 * * *$ & $(0.006)$ & $0.031 * * *$ & $(0.007)$ & $0.091 * * *$ & $(0.010)$ & $-0.033^{* * *}$ & $(0.007)$ & $-0.043^{* * *}$ & $(0.006)$ & $-0.038 * * *$ & $(0.007)$ \\
\hline Age squared & $-0.0003 * * *$ & $(0.0001)$ & $-0.0003 * * *$ & $(0.0001)$ & $-0.0008 * * *$ & $(0.0001)$ & $0.0002^{* * *}$ & $(0.0001)$ & $0.0003^{* * *}$ & $(0.0001)$ & $0.0003^{* * *}$ & $(0.0001)$ \\
\hline Children & $0.040 * * *$ & $(0.016)$ & $0.036 * *$ & (0.019) & $0.146 * * *$ & $(0.023)$ & & & & & & \\
\hline HH Size & $-0.063 * * *$ & $(0.014)$ & $-0.077 * * *$ & $(0.016)$ & $-0.168 * * *$ & $(0.020)$ & & & & & & \\
\hline Secondary & $0.522 * * *$ & $(0.043)$ & $0.489 * * *$ & $(0.055)$ & $0.635 * * *$ & $(0.067)$ & $0.238 * * *$ & $(0.051)$ & $0.082 *$ & $(0.045)$ & $0.189 * * *$ & $(0.047)$ \\
\hline University & $1.103^{* * *}$ & $(0.047)$ & $1.063 * * *$ & $(0.058)$ & $1.320 * * *$ & $(0.069)$ & $0.383 * * *$ & $(0.059)$ & $0.241^{* * *}$ & $(0.051)$ & $0.401^{* * *}$ & $(0.055)$ \\
\hline Student & $1.454 * * *$ & $(0.074)$ & $1.266^{* * *}$ & $(0.090)$ & $1.094 * * *$ & $(0.115)$ & $0.626 * * *$ & $(0.116)$ & $0.326 * * *$ & $(0.092)$ & $0.488 * * *$ & $(0.102)$ \\
\hline Self-employed & $-0.200 * * *$ & $(0.069)$ & $-0.243 * * *$ & $(0.078)$ & $-0.618 * * *$ & $(0.091)$ & $0.287 * * *$ & $(0.104)$ & $0.295 * * *$ & $(0.084)$ & $0.501^{* * *}$ & $(0.102)$ \\
\hline White collar & $0.120 * * *$ & $(0.045)$ & $0.091 *$ & $(0.051)$ & -0.026 & $(0.056)$ & $0.250 * * *$ & $(0.066)$ & $0.239 * * *$ & $(0.052)$ & $0.226 * * *$ & $(0.060)$ \\
\hline House person & $-0.338 * * *$ & $(0.060)$ & $-0.474 * * *$ & $(0.076)$ & $-0.973 * * *$ & $(0.094)$ & 0.079 & $(0.080)$ & -0.068 & $(0.064)$ & 0.011 & $(0.072)$ \\
\hline Unemployed & $-0.531 * * *$ & $(0.064)$ & $-0.580 * * *$ & $(0.078)$ & $-0.673 * * *$ & $(0.092)$ & $-0.311^{* * *}$ & $(0.073)$ & $-0.663 * * *$ & $(0.063)$ & $-0.343 * * *$ & $(0.067)$ \\
\hline Retiree & $-0.350 * *$ & $(0.058)$ & $-0.387 * * *$ & $(0.070)$ & $-0.769 * * *$ & $(0.086)$ & 0.023 & $(0.074)$ & -0.079 & $(0.063)$ & -0.056 & $(0.068)$ \\
\hline Farmer/fisherman & $-0.227 * * *$ & $(0.108)$ & $-0.266^{*}$ & $(0.140)$ & $-0.408 * * *$ & $(0.159)$ & 0.024 & $(0.165)$ & 0.038 & $(0.142)$ & 0.001 & $(0.150)$ \\
\hline HH Income 2nd Quartile & $0.162 * * *$ & $(0.045)$ & $0.158 * * *$ & $(0.055)$ & $0.181 * * *$ & $(0.066)$ & $0.227 * * *$ & $(0.055)$ & $0.253 * * *$ & $(0.048)$ & $0.228 * * *$ & $(0.050)$ \\
\hline HH Income 3rd Quartile & $0.314 * * *$ & $(0.046)$ & $0.268 * * *$ & $(0.056)$ & $0.287 * * *$ & $(0.067)$ & $0.284 * * *$ & $(0.058)$ & $0.370 * * *$ & $(0.050)$ & $0.388 * * *$ & $(0.054)$ \\
\hline HH Income 4th Quartile & $0.419 * * *$ & $(0.050)$ & $0.364 * * *$ & $(0.059)$ & $0.320 * * *$ & $(0.071)$ & $0.504 * * *$ & $(0.065)$ & $0.709 * * *$ & $(0.054)$ & $0.606 * * *$ & $(0.060)$ \\
\hline Small/Medium town & & & & & & & 0.000 & $(0.046)$ & $-0.133 * * *$ & $(0.039)$ & $-0.091 * *$ & $(0.043)$ \\
\hline City & & & & & & & -0.063 & $(0.050)$ & $-0.099 * *$ & $(0.042)$ & $-0.167 * * *$ & $(0.046)$ \\
\hline Candidate countries & $-0.949 * * *$ & $(0.035)$ & $0.258 * * *$ & (0.039) & $-1.144 * * *$ & $(0.051)$ & $-0.509 * * *$ & $(0.039)$ & $-0.735 * * *$ & $(0.033)$ & $-0.440 * * *$ & $(0.036)$ \\
\hline Constant & & & & & & & $2.054 * * *$ & $(0.179)$ & $1.755^{* * *}$ & $(0.151)$ & $1.845^{* * *}$ & $(0.164)$ \\
\hline Log likelihood & $-20,527.24$ & & $-14,013.01$ & & $-10,079.12$ & & $-8,734.46$ & & $-11,075.22$ & & $-9,840.80$ & \\
\hline Pseudo R2 & 0.061 & & 0.045 & & 0.093 & & 0.042 & & 0.074 & & 0.042 & \\
\hline Wald $\chi^{2}$ & $2,435.37^{* * *}$ & & $1,274.67 * * *$ & & $1,716.89 * * *$ & & $738.56^{* * *}$ & & $1,543.71^{* * *}$ & & $790.64^{* * *}$ & \\
\hline No. of observations & 19,854 & & 19,661 & & 19,702 & & 19,293 & & 17,774 & & 18531 & \\
\hline
\end{tabular}

Notes: Estimated with logit or ordered logit; Significance levels: * 5\% and ** $10 \%$. 
Table 8: Individual and aggregate determinants of social capital: Pooled data

\begin{tabular}{|c|c|c|c|c|c|c|c|c|c|c|c|c|}
\hline & \begin{tabular}{|l|} 
Overall Civic \\
Participation \\
\end{tabular} & std. error & $\begin{array}{l}\text { Putnam } \\
\text { Groups }\end{array}$ & std. error & $\begin{array}{c}\text { Olsonian } \\
\text { Groups }\end{array}$ & std. error & $\begin{array}{c}\text { Networks if } \\
\text { depressed }\end{array}$ & std. error & $\begin{array}{c}\text { Networks if } \\
\text { needs job }\end{array}$ & std. error & $\begin{array}{c}\text { Networks to } \\
\text { borrow }\end{array}$ & std. error \\
\hline Female & $-0.258 * * *$ & $(0.055)$ & $-0.220 * * *$ & $(0.065)$ & $-0.195 * * *$ & $(0.068)$ & $0.429 * * *$ & $(0.060)$ & $-0.111 * * *$ & $(0.036)$ & $0.124 * *$ & $(0.050)$ \\
\hline Married & -0.023 & $(0.056)$ & 0.011 & $(0.071)$ & $0.200 * * *$ & $(0.066)$ & -0.021 & $(0.056)$ & -0.015 & $(0.037)$ & 0.039 & $(0.057)$ \\
\hline Age & $0.032 * * *$ & $(0.007)$ & $0.028 * *$ & $(0.012)$ & $0.087 * * *$ & $(0.009)$ & $-0.034 * * *$ & $(0.008)$ & $-0.045 * * *$ & $(0.006)$ & $-0.039 * * *$ & $(0.007)$ \\
\hline Age squared & $-0.0003 * * *$ & $(0.0001)$ & $-0.0003 * *$ & $(0.0001)$ & $-0.0008 * * *$ & $(0.0001)$ & $0.0002 * * *$ & $(0.0001)$ & $0.0003^{* * *}$ & $(0.0001)$ & $0.0003^{* * *}$ & $(0.0001)$ \\
\hline Children & -0.030 & $(0.027)$ & -0.036 & $(0.033)$ & 0.060 & (0.039) & & & & & & \\
\hline HH Size & 0.036 & $(0.023)$ & 0.014 & $(0.026)$ & $-0.073 * *$ & $(0.029)$ & & & & & & \\
\hline Secondary & $0.333 * * *$ & $(0.086)$ & $0.353 * * *$ & $(0.112)$ & $0.419 * * *$ & $(0.096)$ & $0.193 * * *$ & $(0.071)$ & 0.042 & $(0.063)$ & $0.142 *$ & $(0.082)$ \\
\hline University & $0.837 * * *$ & $(0.090)$ & $0.823 * * *$ & $(0.128)$ & $0.908 * * *$ & $(0.091)$ & $0.309 * * *$ & $(0.082)$ & $0.193 * * *$ & $(0.067)$ & $0.300 * * *$ & $(0.087)$ \\
\hline Student & $1.153^{* * *}$ & $(0.118)$ & $0.933 * * *$ & $(0.225)$ & $0.581 * * *$ & $(0.195)$ & $0.520 * * *$ & $(0.132)$ & $0.265 *$ & $(0.137)$ & $0.393 * * *$ & $(0.144)$ \\
\hline Self-employed & 0.039 & $(0.095)$ & -0.064 & $(0.150)$ & $-0.363 * * *$ & $(0.136)$ & $0.341^{* * *}$ & $(0.114)$ & $0.299 * * *$ & $(0.090)$ & $0.524 * * *$ & $(0.107)$ \\
\hline White collar & $0.169 * *$ & $(0.068)$ & 0.129 & $(0.079)$ & 0.064 & $(0.073)$ & $0.274 * * *$ & $(0.070)$ & $0.248 * * *$ & $(0.065)$ & $0.268 * * *$ & $(0.064)$ \\
\hline House person & -0.211 & $(0.153)$ & $-0.394 *$ & $(0.201)$ & $-0.664 * * *$ & $(0.247)$ & 0.110 & $(0.135)$ & 0.038 & $(0.095)$ & $0.193^{* *}$ & $(0.091)$ \\
\hline Unemployed & $-0.430 * * *$ & $(0.079)$ & $-0.462 * * *$ & $(0.095)$ & $-0.563 * * *$ & $(0.130)$ & $-0.281 * * *$ & $(0.101)$ & $-0.623 * * *$ & $(0.081)$ & $-0.348 * * *$ & $(0.082)$ \\
\hline Farmer/fisherman & 0.159 & $(0.248)$ & 0.058 & $(0.261)$ & -0.070 & $(0.325)$ & 0.039 & $(0.183)$ & 0.108 & $(0.144)$ & -0.006 & $(0.157)$ \\
\hline HH Income 2nd Quartile & $0.146 *$ & $(0.072)$ & 0.128 & $(0.091)$ & $0.167 * *$ & $(0.082)$ & $0.182^{* * *}$ & $(0.064)$ & $0.217 * * *$ & $(0.072)$ & $0.162 * *$ & $(0.067)$ \\
\hline HH Income 3rd Quartile & $0.478 * * *$ & $(0.095)$ & $0.426 * * *$ & $(0.132)$ & $0.486 * * *$ & $(0.127)$ & $0.253 * * *$ & $(0.082)$ & $0.358 * * *$ & $(0.071)$ & $0.340 * * *$ & $(0.087)$ \\
\hline HH Income 4th Quartile & $0.513^{* * *}$ & $(0.114)$ & $0.453 * * *$ & $(0.151)$ & $0.466 * * *$ & $(0.170)$ & $0.446^{* * *}$ & $(0.105)$ & $0.709 * * *$ & $(0.088)$ & $0.574 * * *$ & $(0.107)$ \\
\hline Small/Medium town & & & & & & & -0.025 & $(0.058)$ & $-0.129 * *$ & $(0.057)$ & -0.081 & $(0.062)$ \\
\hline City & & & & & & & -0.028 & $(0.065)$ & -0.057 & $(0.086)$ & -0.102 & $(0.074)$ \\
\hline $\begin{array}{l}\text { GDP per capita } \\
\text { (thousands) }\end{array}$ & 0.023 & $(0.024)$ & 0.019 & $(0.027)$ & 0.007 & $(0.022)$ & -0.001 & $(0.017)$ & 0.000 & $(0.018)$ & $-0.029 * *$ & $(0.013)$ \\
\hline Gini coefficient & $-0.049 *$ & $(0.027)$ & $-0.071 * *$ & $(0.034)$ & $-0.064 * *$ & $(0.031)$ & -0.008 & $(0.022)$ & -0.022 & $(0.017)$ & -0.004 & $(0.020)$ \\
\hline Non-corruption & $0.249 * * *$ & $(0.092)$ & $0.337 * * *$ & $(0.099)$ & $0.461^{* * *}$ & $(0.108)$ & 0.156 & $(0.102)$ & 0.022 & $(0.104)$ & $0.292 * * *$ & $(0.085)$ \\
\hline Economic Freedom & $0.422 * *$ & $(0.176)$ & $0.345^{*}$ & $(0.195)$ & 0.116 & $(0.250)$ & -0.027 & $(0.155)$ & 0.161 & $(0.168)$ & -0.170 & $(0.139)$ \\
\hline Candidate countries & $0.942 * * *$ & $(0.323)$ & $2.436 * * *$ & $(0.409)$ & $0.943^{* *}$ & $(0.404)$ & -0.042 & $(0.300)$ & -0.414 & $(0.311)$ & -0.220 & $(0.244)$ \\
\hline Constant & & & & & & & 1.446 & $(1.173)$ & 1.131 & $(0.951)$ & $1.864 *$ & $(0.957)$ \\
\hline F-statistics & $12.88 * * *$ & & $19.01^{* * *}$ & & $36.11^{* * *}$ & & $21.91^{* * *}$ & & $71.25 * * *$ & & $14.76^{* * *}$ & \\
\hline No. of observations & 19019 & & 18,841 & & 18,882 & & 18,460 & & 17,010 & & 17,758 & \\
\hline
\end{tabular}


Notes: Estimated with logit or ordered logit; Significance levels: * 5\% and ** 10\%. Standard errors are adjusted to account for the fact that country-level and individual variables are observed at different levels of aggregation. GDP per capita is in thousands of US dollars adjusted for purchasing-power parity. Noncorruption is the corruption perception index as compiled by Transparency International, higher values indicate less corruption. Economic freedom is the index compiled by the Frasier Institute. 


\section{DAVIDSON INSTITUTE WORKING PAPER SERIES - Most Recent Papers}

The entire Working Paper Series may be downloaded free of charge at: www.wdi.bus.umich.edu

CURRENT AS OF 4/29/05

\begin{tabular}{|c|c|c|}
\hline Publication & Authors & Date \\
\hline $\begin{array}{l}\text { No. 766: Formation of social capital in Central and Eastern Europe: } \\
\text { Understanding the gap vis-à-vis developed countries }\end{array}$ & Jan Fidrmuc and Klarita Gërxhani & Apr. 2005 \\
\hline $\begin{array}{l}\text { No. 765: Do Regional Integration Agreements Increase Business-Cycle } \\
\text { Convergence? Evidence From APEC and NAFTA }\end{array}$ & $\begin{array}{l}\text { Viviana Fernandez and Ali M. } \\
\text { Kutan }\end{array}$ & Apr. 2005 \\
\hline $\begin{array}{l}\text { No. 764: State Regulations, Job Search and Wage Bargaining: A Study } \\
\text { in the Economics of the Informal Sector }\end{array}$ & Maxim Bouev & Apr. 2005 \\
\hline $\begin{array}{l}\text { No. 763: The Feldstein-Horioka Puzzle Revisited: An "European- } \\
\text { Regional” Perspective }\end{array}$ & $\begin{array}{l}\text { Jérôme Hericourt and Mathilde } \\
\text { Maurel }\end{array}$ & Apr. 2005 \\
\hline $\begin{array}{l}\text { No. 762: Transatlantic Differences in Labour Markets Changes in Wage } \\
\text { and Non-Employment Structures in the 1980s and the 1990s }\end{array}$ & Patrick A. Puhani & Mar. 2005 \\
\hline $\begin{array}{l}\text { No. 761: Resolution, Recovery and Survival: The Evolution of Payment } \\
\text { Disputes in Post-Socialist Europe }\end{array}$ & William Pyle & Mar. 2005 \\
\hline $\begin{array}{l}\text { No. 760: Official Foreign Exchange Interventions in the Czech } \\
\text { Republic: Did They Matter? }\end{array}$ & Balázs Égert and Luboš Komárek & Mar. 2005 \\
\hline $\begin{array}{l}\text { No. 759: Assessing Market Expectations on Exchange Rates and } \\
\text { Inflation: A Pilot Forecasting System for Bulgaria }\end{array}$ & $\begin{array}{l}\text { Michael Berlemann, Kalina } \\
\text { Dimitrova, \& Nikolay Nenovsky }\end{array}$ & Mar. 2005 \\
\hline No. 758: Attitudes and Performance: An Analysis of Russian Workers & $\begin{array}{l}\text { Susan J. Linz and Anastasia } \\
\text { Semykina }\end{array}$ & Mar. 2005 \\
\hline $\begin{array}{l}\text { No. 757: Barter, Credit, and Welfare: A theoretical inquiry into the } \\
\text { barter phenomenon in Russia }\end{array}$ & José Noguera and Susan J. Linz & Mar. 2005 \\
\hline $\begin{array}{l}\text { No. 756: Sorting, Selection, and Transformation of the Return to } \\
\text { College Education In China }\end{array}$ & $\begin{array}{l}\text { Belton M. Fleisher, Haizheng Li, } \\
\text { Shi Li, and Xiaojun Wang }\end{array}$ & Mar. 2005 \\
\hline $\begin{array}{l}\text { No. 755: Foreign Exchange Interventions in Emerging Europe: } \\
\text { Should We Give a Damn? The Case of Croatia and Turkey }\end{array}$ & Balázs Égert and Maroje Lang & Mar. 2005 \\
\hline $\begin{array}{l}\text { No. 754: Targeting Relative Inflation Forecast as Monetary Policy } \\
\text { Framework for Adopting Euro }\end{array}$ & Lucjan T. Orlowski & Feb. 2005 \\
\hline $\begin{array}{l}\text { No. 753: Internet Entrepreneurship: Networks and Performance of } \\
\text { Internet Ventures In China }\end{array}$ & Bat Batjargal & Feb. 2005 \\
\hline $\begin{array}{l}\text { No. 752: Network Triads: Transitivity, Referral and Venture Capital } \\
\text { Decisions in China and Russia }\end{array}$ & Bat Batjargal & Feb. 2005 \\
\hline $\begin{array}{l}\text { No. 751: Software Entrepreneurship: Knowledge Networks and } \\
\text { Performance Of Software Ventures In China and Russia }\end{array}$ & Bat Batjargal & Feb. 2005 \\
\hline $\begin{array}{l}\text { No. 750: Retained State Shareholding in Chinese PLCs: Does } \\
\text { Government Ownership Reduce Corporate Value? }\end{array}$ & Lihui Tian and Saul Estrin & Feb. 2005 \\
\hline No. 749: Financial Development and Technology & Solomon Tadesse & Feb. 2005 \\
\hline No. 748: Banking Fragility and Disclosure: International Evidence & Solomon Tadesse & Feb. 2005 \\
\hline $\begin{array}{l}\text { No. 747: Consolidation, Scale Economies and Technological Change in } \\
\text { Japanese Banking }\end{array}$ & Solomon Tadesse & Feb. 2005 \\
\hline $\begin{array}{l}\text { No. 746: Trade Creation and Diversion Effects of Europe’s Regional } \\
\text { Liberalization Agreements }\end{array}$ & Yener Kandogan & Feb. 2005 \\
\hline No. 745: Quality of Institutions, Credit Markets and Bankruptcy & Christa Hainz & Feb. 2005 \\
\hline $\begin{array}{l}\text { No. 744: How Transition Paths Differ: Enterprise Performance in Russia } \\
\text { and China }\end{array}$ & Sumon Bhaumik and Saul Estrin & Jan. 2005 \\
\hline $\begin{array}{l}\text { No. 743: Inflation Targeting, Between Rhetoric and Reality. The Case } \\
\text { of Transition Economies }\end{array}$ & Daniel Daianu and Laurian Lungu & Jan. 2005 \\
\hline $\begin{array}{l}\text { No. 742: How Does Law Affect Finance? An Empirical Examination of } \\
\text { Tunneling in an Emerging Market }\end{array}$ & $\begin{array}{l}\text { Vladimir Atanasov, Conrad S. } \\
\text { Ciccotello, \& Stanley B. Gyoshev }\end{array}$ & Jan. 2005 \\
\hline $\begin{array}{l}\text { No. 741: Do Insider Trading Laws Matter? Some Preliminary } \\
\text { Comparative Evidence }\end{array}$ & Laura Nyantung Beny & Jan. 2005 \\
\hline $\begin{array}{l}\text { No. 740: Autopsy on an Empire: Understanding Mortality in Russia and } \\
\text { the Former Soviet Union }\end{array}$ & $\begin{array}{l}\text { Elizabeth Brainerd and David M. } \\
\text { Cutler }\end{array}$ & Jan. 2005 \\
\hline $\begin{array}{l}\text { No. 739: Not Separate, Not Equal: Poverty and Inequality in Post- } \\
\text { Apartheid South Africa }\end{array}$ & $\begin{array}{l}\text { Johannes G. Hoogeveen and Berk } \\
\text { Özler }\end{array}$ & Jan. 2005 \\
\hline
\end{tabular}

